\title{
STARANIA SEJMIKÓW SZLACHECKICH O NALEŻYTE GROMADZENIE, ZABEZPIECZANIE, OPRACOWANIE I PRZECHOWYWANIE AKT SĄDÓW SZLACHECKICH W XVI-XVIII WIEKU. GŁÓWNE PROBLEMY
}

\author{
Janusz Łosowski \\ Uniwersytet Marii Curie-Skłodowskiej w Lublinie
}

\begin{abstract}
\section{ENDEAVORS OF THE NOBILITY DIETINES TO ENSURE PROPER OF RECORDS OF THE NOBILITY COURTS IN THE $16^{\mathrm{TH}}-18^{\mathrm{TH}}$ CENTURIES. MAIN PROBLEMS} ACCESSION, PROTECTION, CLASSIFICATION AND ACCESSIBILITY
\end{abstract}

Formally, the records of the land courts (sady ziemskie), castle courts (sady grodzkie) and chamberlain courts (sady podkomorskie) were in the custody of the chancellery and court officials. However, it often happened that it was beyond their capabilities to ensure safety and proper storage conditions for court registers and records, and that is why it was necessary to make the nobility at large interested in improving this situation. The problems connected with storing and protecting the records of these courts were often the subject of debates of the dietines (sejmiki). The paper examines the resolutions on the matter by the dietines of Greater Poland, Cracow, Chełm, the General Dietine of the Ruthenian Voivodeship, and the Land Dietines (sejmiki ziemskie) of Lviv, Przemyśl, Sanok and Halicz. It can be said that the nobility were vividly interested in the protection of court records, which contained legal evidence necessary for the owners of landed estates and real property. They also saw to it that the missing records were restored. The dietines often took care of archives and provided vast sums of money for archive facilities, and sometimes even supported initiatives aimed at buying separate buildings for archival and office purposes. This may show the great documentation culture of the Polish nobility and their high legal consciousness.

Key words: dietines, Polish nobility, court records, archives, documentation culture.

Slowa kluczowe: sejmiki, szlachta polska, sądy szlacheckie, archiwa, kultura prawna. 


\section{WSTĘP}

Akta sądów ziemskich, grodzkich i podkomorskich formalnie pozostawały pod nadzorem urzędników kancelaryjnych i sądowych, a więc pisarzy ziemskich, grodzkich oraz podkomorzych i komorników. Oni odpowiadali za umieszczenie dokumentacji urzędowej w odpowiednich pomieszczeniach, utrzymanie jej w należytym porządku oraz zabezpieczenie przed zniszczeniem, kradzieżą czy zagubieniem. Bardzo często jednak zdarzało się, że zapewnienie księgom i aktom odpowiednich warunków przechowywania przekraczało możliwości poszczególnych urzędników, dlatego sprawą ich poprawy musiano zainteresować wyższych urzędników, a nawet szlachtę.

W praktyce problemy związane z przechowywaniem i zabezpieczaniem dokumentacji wymienionych sądów stawały się przedmiotem obrad sejmików szlacheckich. Szlachta była bowiem żywotnie zainteresowana należytym zabezpieczeniem ksiąg ziemskich, grodzkich oraz podkomorskich. Dokumentacja tych sądów miała charakter urzędowy i związana była z terenem powiatów czy też województw. Zawierała szlacheckie kontrakty kupna-sprzedaży, darowizny, zamiany, zastawu lub dzierżawy, a także dekrety w sprawach dotyczących posiadania dóbr czy też ich samych. Stanowiła też dowód różnych czynności politycznych, podatkowych, a nawet o charakterze militarnym.

Szlachtę interesowały również problemy organizacji pracy kancelarii grodzkich, ziemskich oraz podkomorskich, Trybunału Koronnego, a nawet kancelarii królewskiej, w tym Metryki Koronnej. Szlacheccy petenci wymienionych urzędów potrafili też na sejmikach upominać się o wynagrodzenie dla zasłużonych pracowników kancelaryjnych, uchwalając dla nich różnego rodzaju gratyfikacje pieniężne oraz innego rodzaju nagrody. Kwestie te, istotne w dziejach zarówno sejmików, jak i kancelarii okresu staropolskiego, powinny być odrębnie badane, dlatego w tym tekście nie będą poddane analizie.

Dbając o zasadnicze sprawy natury politycznej, gospodarczej, lub nawet o kwestie kultury oraz sprawy religijne, uczestnicy sejmików zwracali też uwagę na zagadnienia dokumentacji, które obecnie mogą się wydawać drugorzędne czy wręcz nieistotne. Całkowicie uzasadnia to podjęcie analizy tego problemu. Powinna ona ułatwić określenie głównych cech wspomnianego zjawiska oraz jego najważniejszych przejawów na różnych obszarach Rzeczypospolitej.

\section{LITERATURA PRZEDMIOTU}

Dotychczasowe rezultaty badań zainteresowania sejmikującej szlachty kwestiami zabezpieczenia dokumentacji sądów szlacheckich nie są zadowalające. Należy jednak stwierdzić, że bardzo dużo różnorodnych danych faktograficznych o kancelariach z terenu ziem ruskich przekazał Przemysław Dąbkowski, doskonały znawca 
dawnego prawa i praktyki funkcjonowania sądów szlacheckich okresu staropolskiego. W jego przedwojennych pracach odnaleźć można liczne informacje o stanie dokumentacji sądowej i jej losach ${ }^{1}$. Wiele jego publikacji dotyczyło uchwał sejmikowych podejmowanych w celu poprawy warunków przechowywania akt sądowych, ich lepszego zabezpieczenia oraz ewidencjonowania. W typowo faktograficznych opracowaniach tego badacza zabrakło jednak jakichkolwiek prób uogólnień wypływających z analizy zebranych faktów.

Na podstawie prac Dąbkowskiego szereg trafnych uogólnień dotyczących zainteresowania sejmiku ruskiego sprawami dokumentacji i archiwów umieścił w swojej pracy Tadeusz Kostkiewicz. Stwierdził on, że sejmik ten otaczał archiwa opieką, przeznaczając na restaurację ich pomieszczeń spore sumy oraz popierając niekiedy inicjatywy zmierzające do kupna osobnych budynków na cele kancelaryjno-archiwalne ${ }^{2}$. Wymieniony autor dostrzegł też mobilizowanie przez ten sejmik starostów grodowych do naprawy zamków, w których znajdowały się pomieszczenia kancelaryjno-archiwalne. W jego opracowaniu zabrakło jednak faktografii, która umożliwiłaby dokładniejsze poznanie poszczególnych inicjatyw sejmikowych.

Badacze powojenni o wspomnianych kwestiach pisali znacznie mniej. Janina Bielecka w swojej klasycznej już rozprawie poświęconej kancelarii grodzkiej poznańskiej pominęła kwestie lokalowe ${ }^{3}$. Andrzej Tomczak w podręczniku dziejów archiwów stwierdził zainteresowanie szlachty stanem pomieszczeń, w których przechowywano księgi grodzkie w XVII wieku ${ }^{4}$. Nie wspomniał jednak o zainteresowaniu szlachty losem ksiąg ziemskich czy też trybunalskich. Identyczne informacje znalazły się w toruńskim podręczniku archiwistyki zawierającym część poświęconą dziejom archiwów polskich ${ }^{5}$.

W latach 90. ubiegłego wieku na zagadnienie zainteresowań dokumentacyjnych szlachty zwrócili też uwagę Waldemar Chorążyczewski i Krzysztof Syta. Najpierw przedstawili analizę konstytucji sejmowych regulujących funkcjonowanie archiwów grodzkich, ziemskich i centralnych oraz kwestie rewizji i przepisywania akt ${ }^{6}$. W drugim artykule autorzy ci poszerzyli zakres analizy o problemy uchwał sejmikowych

${ }^{1}$ P. Dąbkowski, Z przeszłości ksiag grodzkich i ziemskich buskich, „Kwartalnik Historyczny” 1915, t. 29, s. 1-16; idem, Z przeszłości ksiag grodzkich i ziemskich żydaczowskich [w:] Księga pamiątkowa ku czci Bolesława Orzechowicza, t. 1, Lwów 1916, s. 234-255; idem, Księgi sądowe halickie za czasów polskich, „Przegląd Prawa i Administracji” 1917, s. 1-20; idem, Palestra i księgi sądowe sanockie w dawnej Polsce, „Pamiętnik Historyczno-Prawny” 1925, t. 1, z. 6, s. 1-55; idem, Księgi sadowe lwowskie w dawnej Polsce, „Studia nad historią prawa polskiego”, t. XVI, z. 1, Lwów 1937, s. 1-158; idem, Ksiegi sqdowe przemyskie i przeworskie $w$ dawnej Polsce, „Rocznik Towarzystwa Przyjaciół Nauk w Przemyślu" 1928-1937, t. VII, s. 3-86.

${ }^{2}$ T. Kostkiewicz, Działalność kulturalna sejmiku ruskiego, „Pamiętnik Historyczno-Prawny” 1939 , t. 13 , z. 2 , s. $30-36$.

${ }^{3}$ J. Bielecka, Kancelaria grodzka wielkopolska w XVI-XVIII wieku, „Studia Źródłoznawcze” 1957, t. 1, s. 119-153.

${ }^{4}$ A. To m c zak, Zarys dziejów archiwów polskich, Toruń 1982, s. 60-63.

${ }^{5}$ H. Robótka, B. Rys zew sk i, A. To m c zak, Archiwistyka, Warszawa 1989, s. 218.

${ }^{6}$ W. Chorąży czew ski, K. Sy ta, Ustawodawstwo archiwalne sejmów polskich od XV do potowy XVIII w. Zarys problemu [w:] Archiwistyka i bibliotekoznawstwo. Prace dedykowane Profesorowi Bohdanowi Ryszewskiemu, Warszawa 1997, s. 30-53. 
i instrukcji poselskich dotyczących problemów dokumentacyjnych ${ }^{7}$. Problem postulatów sejmików w sprawach archiwalnych wyraźnie jednak stanowił dla nich zagadnienie drugorzędne, co znalazło odbicie w zdecydowanie mniejszej ilości odnośników źródłowych, wynoszącej około $25 \%$ wszystkich. Skala zainteresowania szlachty sprawami akt grodzkich, ziemskich i podkomorskich była znacznie większa, niż wynikało to z opracowania wyżej wymienionych autorów. Skłoniło mnie to do uważniejszego zajęcia się tym problemem.

Sporo informacji świadczących o zainteresowaniu szlachty podał w swoich cennych pracach Michał Zwierzykowski. Ograniczył się jednak do terenu Wielkopolski i skupił uwagę na wybranych problemach, nie podejmując próby zarysowania całości problemu ani też wykroczenia poza wspomniany obszar. W swojej pierwszej, jeszcze studenckiej, pracy przedstawił wybrane przykłady regulowania przez sejmik średzki niektórych czynności archiwalnych, takich jak rewizje dokumentacji, porządkowanie, rewindykowanie, a także warunki jej przechowywania ${ }^{8}$. W kolejnym artykule opisał również działania sejmiku wielkopolskiego w sprawie zabezpieczenia akt sądowych oraz poprawy stanu fizycznego zamku poznańskiego' ${ }^{9}$ W następnym tekście zwrócił uwagę na zabiegi szlachty mające na celu znalezienie innych pomieszczeń dla kancelarii grodzkiej i archiwum w latach 1714-1718, po zniszczeniu pomieszczeń na zamku poznańskim wcześniej wykorzystywanych do tych celów ${ }^{10}$. Także w swojej pracy doktorskiej nie pominął problemów archiwalnych, przedstawiając przykłady troski szlachty wielkopolskiej o stan i kompletność Komisji Skarbowej Poznańskiej ${ }^{11}$.

Nieco informacji potwierdzających troskę szlachty o poprawę warunków przechowywania akt grodzkich i ziemskich przyniosły późniejsze prace. Kilka faktów dotyczących przechowywania akt chełmskich w zamojskim ratuszu i zainteresowania nią szlachty chełmskiej podał Robert Jop ${ }^{12}$. Więcej informacji o zaangażowaniu sejmiku chełmskiego w tej sprawie zamieściłem w swojej monografii chełmskiej kancelarii grodzkiej, o czym niżej ${ }^{13}$. W pracach tych - ze względu na ściśle

${ }^{7}$ Iidem, Stosunek szlachty polskiej $w$ XV-XVIII w. do ksiag sądów partykularnych $w$ świetle ustaw sejmowych i sejmikowych, „Miscellanea Historico-Archivistica” 1999, t. X, s. 3-26.

${ }^{8}$ M. Z w i er zy k ow s k i, Problematyka archiwalna w uchwałach sejmiku województw poznańskiego i kaliskiego w czasach saskich (1696-1763) [w:] Pamiętnik II Ogólnopolskiego Zjazdu Studentów Archiwistyki, Poznań 16-17 kwietnia 1998 r., red. I. Ma m c zak-Ga dk ow s k a, Poznań 1998, s. 43-44.

9 Idem, Sejmikowe próby remontu zamku poznańskiego w XVIII wieku, „Kronika Miasta Poznania” 2004, nr 4, s. 279-302.

${ }^{10}$ Idem, Szlacheckie instytucje sądowe i samorzadowe na Starym Rynku od XVI do XVIII wieku, „Kronika Miasta Poznania” 2003, nr 2, s. 240.

${ }^{11}$ Idem, Komisja Skarbowa Poznańska. Z dziejów sejmikowej administracji i sąownictwa skarbowego w Wielkopolsce w XVII i XVIII wieku, Poznań 2003, s. 209.

12 R. J o p, Środowisko urzędnicze kancelarii grodzkich w Chetmie, Lublinie i Krasnymstawie w drugiej połowie XVII wieku, Lublin 2003, s. 128. Autor ten mógł na ten temat napisać znacznie więcej, na co zwrócił uwagę oceniający jego pracę R. Kozyrski. Zob. recenzję tegoż w „Roczniku Chełmskim” 2006 , t. 10 , s. 413.

13 J. Ło sow ski, Kancelaria grodzka chetmska od XV do XVIII wieku. Studium o urzędzie, dokumentacji jej formach i roli w życiu społeczeństwa staropolskiego, Lublin 2004, s. 148-151. 
określoną tematykę - nie można było zamieścić informacji spoza terenu ograniczonego do jednego województwa i ziemi lub jedynie powiatu.

Charakterystyczne, że problem zaangażowania sejmików w sprawy zabezpieczenia dokumentacji był z reguły pomijany przez autorów monografii poświęconych ich działalności ${ }^{14}$. Z tego powodu trudno jednak czynić większe zarzuty autorom wspomnianych opracowań. Zakres rzeczowy spraw rozpatrywanych przez sejmiki był tak szeroki, że analiza w jednej monografii każdego zagadnienia będącego w kręgu zainteresowania zebranej szlachty nie jest w zasadzie możliwa. Tym bardziej na uznanie zasługują autorzy monografii poszczególnych sejmików, którzy zwrócili uwagę na tego rodzaju informacje i podali je w swoich opracowaniach. Wśród nich można wymienić opracowania Andrzeja B. Zakrzewskiego ${ }^{15}$, Jerzego Ternesa ${ }^{16}$ oraz Anny Burkietowicz ${ }^{17}$.

Stwierdzając niedostatek opracowań dotyczących zagadnień dokumentacyjnych będących przedmiotem zainteresowania sejmików, należy je odrębnie badać, gdyż tylko w ten sposób będzie możliwe uzyskanie pełnego obrazu zainteresowań szlachty i jej społecznej aktywności. W dotychczasowych badaniach poświęconych sejmikom istnieje znacząca luka, którą należy wypełnić, zwłaszcza że wydane wcześniej akta głównych sejmików krakowskiego, wielkopolskiego i ruskiego dostarczają obfitego materiału źródłowego. Uzupełniono je materiałem aktowym ziemi chełmskiej, głównie rękopiśmiennym i tyko w części wydanym drukiem. Artykuł ten ze względu na ograniczone ramy rzeczowe, a także wykorzystanie w nim jedynie wybranego materiału źródłowego, nie może stanowić opracowania wyczerpującego problematykę. Z tego powodu należy go traktować jedynie jako wstępne rozpoznanie problematyki, które ma ułatwić opracowanie przyszłej monografii.

14 Na przykład J.A. Gierowski, Sejmik generalny księstwa mazowieckiego, Wrocław 1948; J. Włodarczyk, Sejmiki łęczyckie, Łódź 1973; K. Przyboś, Sejmik województwa krakowskiego w czasach saskich (1697-1763), Kraków 1981; Z. Trawi cka, Sejmik województwa sandomierskiego w latach 1572-1696, Kielce 1985; A. F il i p c zak - K o c u r, Sejmik sieradzki za Wazów (1587-1668), Opole 1989; D. Bogdan, Sejmik warmiński w XVI i pierwszej polowie XVII wieku, Olsztyn 1994; J. Choińska-Mika, Sejmiki mazowieckie w dobie Wazów, Warszawa 1998; M. Ujma, Sejmik lubelski 1572-1696, Warszawa 2003; R. Kozyrs ki, Sejmik szlachecki ziemi chetmskiej (1648-1717), Lublin 2006; K. Ma zu r, W stronę integracji z Korona. Sejmiki Wolynia i Ukrainy w latach 1569-1648, Warszawa 2006.

15 A.B. Zakrzewski, Sejmiki Wielkiego Księstwa Litewskiego XVI-XVIII w. Ustrój i funkcjonowanie: sejmik trocki, Warszawa 2000, s. 200. Równolegle autor ten opublikował artykuł poświęcony problemowi starań szlachty trockiej o pomieszczenia archiwalne Budowa archiwów szlachty trockiej, ,Miscellanea Historico-Archivistica" 2000, t. XI, s. 111-118.

16 J. Ternes, Sejmik chetmski za Wazów (1587-1668), Lublin 2004, s. 76-77.

17 A. B urki et ow i c z, Sejmik sieradzki w latach 1669-1717, Sieradz 2009, s. 58-59. 


\section{SZLACHECKA ŚWIADOMOŚĆ ZNACZENIA AKT GRODZKICH I ZIEMSKICH}

Zainteresowanie dokumentacją sądów ziemskich, grodzkich i podkomorskich wynikało nie tylko ze znajomości tych instytucji. Prawie każdy szlachcic musiał się z nimi zetknąć w swoim życiu. Przedstawiciele stanu szlacheckiego niemal powszechnie stawali przed sądami w charakterze stron w sprawach spornych. Zdarzało się też, że występowali w sprawach kryminalnych jako poszkodowani lub oskarżeni, a także w roli świadków składających zeznania w trakcie przesłuchań. Bardzo często szlachta składała w kancelariach grodzkich różnego rodzaju oświadczenia w postaci manifestów, niejednokrotnie też stawała przed sądami czy urzędami grodzkimi w celu uwierzytelnienia skryptów dłużnych lub transakcji kupna-sprzedaży. A jeśli niektórzy osobiście nie mieli okazji stawienia się w żadnej kancelarii grodzkiej lub ziemskiej, to na pewno niejeden raz wysłuchiwali treści uniwersałów króla, hetmana czy podskarbiego lub innych wyższych urzędników, które po aktykowaniu w aktach grodzkich były odczytywane przez woźnych na rynkach miast.

Pewna grupa szlachty miała osobiste doświadczenia z pracy w kancelarii grodzkiej czy też ziemskiej, najczęściej z okresu młodości u progu swojej kariery urzędniczej bądź politycznej. Pracując w charakterze palestrantów zajmujących się sporządzaniem czystopisów, ich kolacjonowaniem, przeprowadzaniem kwerend, a nawet pełnieniem obowiązków pełnomocników procesujących się stron, szlachcic miał okazję do poznania wartości ksiąg sądowych i to zarówno dawnych, jak i pochodzących z czasów jemu współczesnych. Jego wiedza o funkcjonowaniu kancelarii oraz specyfice przechowywanych w nich akt dorównywała kompetencjom zatrudnionego w nich personelu fachowego.

Teksty laudów sejmikowych zawierają szereg sformułowań świadczących o wysokiej ocenie wartości dowodowej danych ksiąg sądowych. W laudum sejmiku szlachty chełmskiej z 1690 roku akta ziemskie i grodzkie określono jako „wielki

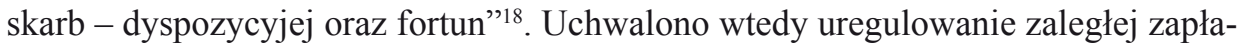
ty za przechowywanie akt grodzkich i ziemskich chełmskich oraz krasnostawskich na ratuszu w Zamościu. Fakt zabezpieczania dokumentacji w innym mieście także potwierdzał wysoką ocenę tej użytecznej dla szlachty dokumentacji.

W roku 1708 szlachta wielkopolska zgromadzona na sejmiku w Środzie uchwaliła wynagrodzenie dla regentów grodzkich kancelarii wielkopolskich za, jak to określono, ,sollicitudinem około ksiąg i archiwum fortun naszych"19. Regenci poznański i kaliski za opiekę nad aktami mieli otrzymać po 500 zł gratyfikacji finansowej, a ich odpowiednikom gnieźnieńskiemu i kaliskiemu zagwarantowano po 200 zł. Wymienionych urzędników zachęcono też, ,aby nie ustawali w ochocie swojej fideliter konserwując akta"20.

\footnotetext{
${ }^{18}$ Archiwum Państwowe w Lublinie (dalej: APL), Akta grodzkie chełmskie (dalej: Agch), Relationes, manifestationes, oblatae (dalej: RMO), syg. 111, k. $464 \mathrm{v}$.

${ }_{19}$ Akta sejmikowe województw poznańskiego i kaliskiego (dalej: Akt. sej. poz.). Lata 1696-1732, wyd. M. Zwierzyk ow ski, Poznań 2008, s. 525 (29 X 1708).

${ }^{20}$ Ibidem.
} 
W uzasadnieniu przyznania regentom grodzkim wymienionych sum użyto bardzo przemawiającego argumentu. Interesujące jest, że nie odwoływano się do racji prawnych, historycznych czy też kulturowych, stwarzających podstawę do ochrony i zachowania akt sądowych, tylko wskazano na interes materialny szlachty. Określenie tej dokumentacji mianem ,archiwum fortun” wymownie świadczyło o świadomości dokumentacyjnej wielkopolskiej szlachty. W pełni uświadamiała sobie ona związek między należytym zachowaniem akt i ich fizyczną dostępnością dla wszystkich zainteresowanych a bezpiecznym posiadaniem dóbr ziemskich stanowiącym podstawę stabilności materialnej posiadaczy czy też właścicieli.

Świadectwa traktowania ksiąg grodzkich jako skarbnicy dowodów szlacheckiego stanu posiadania pochodzą również z lat późniejszych. W roku $1715 \mathrm{w}$ laudum tego sejmiku średzkiego upomniano się o przepisanie na czysto (aktykację) ksiąg grodzkich, czego zaniedbał wcześniejszy pisarz grodzki poznański, podczaszy poznański Wojciech Bułakowski. Wykonania tych prac musiał dopilnować jego następca Franciszek Radzewski. Zaniedbanie tych prac kancelaryjnych jednoznacznie potraktowano jako szkodzenie ,fortunom szlacheckim” przez urzędników grodzkich ${ }^{21}$. Podobnych sformułowań używano też w innych uchwałach sejmiku wielkopolskiego, między innymi z roku $1719^{22}$. Szlachta kujawska niemal identycznie pojmowała funkcję ksiąg sądowych. W laudum sejmiku radziejowskiego z roku 1711 stwierdzono przewiezienie akt grodzkich do ich dawnego miejsca przechowywania po ustaniu zarazy, określając je jako „depositorium fortun ślacheckich”23.

Z niektórych wzmianek źródłowych można wnioskować, że podstawą znaczenia akt grodzkich i ziemskich było nie tylko odgrywanie przez nie roli repozytorium świadectw stanu posiadania szlachty. Niektórzy przedstawiciele stanu szlacheckiego pojmowali ich funkcję dowodową znacznie szerzej. Po klęsce pod Batohem w roku 1652 szlachta chełmska, obawiając się ponownego ataku oddziałów kozackich i tatarskich, postanowiła zabezpieczyć akta grodzkie i ziemskie chełmskie oraz krasnostawskie w ufortyfikowanym Zamościu. Stało się to dzięki inicjatywie administratora zamojskiego oraz łowczego przemyskiego Walentego Fredry. W liście do komisarzy ziemi chełmskiej datowanym na 9 lipca 1652 roku zapewnił on adresatów, że księgi zostały złożone „w sklepie górnym” ratusza, który określił jako reconditorium ${ }^{24}$, co świadczy o dobrych warunkach ich przechowywania. Fredro uznał, że akta „są to stróże naszej czci i substancyjej"25.

Niewątpliwie miał na tu myśli majątki szlachty (,substancyje”), można natomiast mieć wątpliwości, co chciał przekazać, przypisując aktom ziemskim i grodzkim bliżej nieokreśloną rolę w obronie czci szlacheckiej. Prawdopodobnie chodziło mu

21 Ibidem, s. 786.

22 „Aktykacje ksiąg grodzkich, aby ichm. panowie grodzcy pisarze sine mora fortunom szlacheckim nociva procurrent obstringimus ich [...]". Ibidem, s. 786.

23 A. Pawiński, Dzieje ziemi kujawskiej oraz akta historyczne do nich stużące. Rządy sejmikowe $w$ epoce królów elekcyjnych 1572-1795, t. 4: Lauda i instrukcje 1700-1733 (dalej: Lauda i instrukcje), Warszawa 1888, s. 202 (14 IV 1715). W. Ch or ą ży c ze w s k i, K. S y ta, Stosunek szlachty polskiej..., s. 7.

${ }^{24}$ APL, Akta grodzkie lubelskie (dalej: Agl), RMO, syg. 74, k. 177-177v; J. Ło o ow ski, op. cit., S. 148 .

25 APL, Agl, RMO, syg. 74, k. 177-177v. 
o zaakcentowanie znaczenia dokumentacji jako dowodu przynależności stanowej niemal każdego szlachcica, o ile on i jego przodkowie stawali przed sądami ziemskimi bądź grodzkimi lub oblatowali w kancelarii grodzkiej jakikolwiek dokument. Nie należy też wykluczyć, że autor wymienionego listu zamierzał zwrócić uwagę jego adresatów na rolę polityczną i militarną szlachty w życiu politycznym oraz systemie obronnym ówczesnego państwa. Nic więc dziwnego, że akta sądów szlacheckich nazwano „wielkim skarbem”, co uzasadniało ponoszenie kosztów ich długoletniego zabezpieczania w Zamościu ${ }^{26}$.

Świadomość podwójnej użyteczności ksiąg sądów szlacheckich znalazła również wyraz w instrukcji sejmiku kijowskiego z roku 1682. Tamtejsi ziemianie wprowadzili do niej zapis, w którym podkreślali konieczność domagania się zwrotu akt grodzkich i ziemskich znajdujących się w Kijowie i uzasadnili to dowodową rolą dokumentacji. W tekście uchwały dobitnie stwierdzono, że w wymienionych aktach są „fortun i honorów naszych munimenta” ${ }^{27}$. Można przypuszczać, że w ten sposób chciano podkreślić użyteczność akt przy potwierdzaniu zarówno stanu posiadania szlachty, jak i wszelkich przejawów aktywności obywatelskiej, w tym piastowania urzędów oraz podejmowania innych działań o charakterze politycznym.

\section{TROSKA O POMIESZCZENIA KANCELARYJNE I ARCHIWALNE}

Kluczowym problemem okazała się troska o zapewnienie kancelariom ziemskim i grodzkim oraz zgromadzonej w nich dokumentacji odpowiednich pomieszczeń, szczególnie w sytuacjach gdy dotychczasowe uległy zniszczeniu lub daleko idącej ruinie. Szlachta dobrze zdawała sobie sprawę z wagi tego zagadnienia. Wszak złe warunki przechowywania mogły spowodować drastyczne pogorszenie stanu fizycznego akt, a tym samym pozbawić ją znajdujących się w nich dowodów prawnych dokumentujących stan posiadania właścicieli ziemskich, co bardzo utrudniało obronę w przypadku prób jego podważania.

W grodach wielkopolskich niezła pod tym względem sytuacja, jaka istniała w XVI i XVII wieku, diametralnie zmieniła się w okresie wojny północnej. W Poznaniu stosunkowo dobre pomieszczenia zajmowane przez kancelarię grodzką w zamku położonym na Górze Przemysława tak bardzo pogorszyły się na skutek działań wojennych, że sejmik wielkopolski obradujący 10 grudnia 1710 roku w Środzie musiał się zgodzić na przeniesienie jej do innego pomieszczenia wynajętego w mieście, $\mathrm{z}$ zastrzeżeniem, że sytuacja taka nie powinna trwać dłużej niż jeden miesiąc. Rozwiązanie takie miało też swoje negatywne strony. Protokoły akt, w których zapisywano pierwsze wzmianki o dokonanych czynnościach prawnych bądź transakcjach, posiadające z kancelaryjnego punktu widzenia znacznie większą wartość niż czystopisy, musiały być tuż przed

\footnotetext{
26 Ibidem, syg. 106, k. 415v (laudum z 11 IX 1684).

27 Archiv' Ûgozapadnoj Rossì izdavaemyj Vremiennô̂ kommìsieû dlâ razbora drevnich 'aktov', č. 1, t. 2, Kiev' 1888, s. 429 (z 16 XII 1682).
} 
zachodem słońca z powrotem zabierane przez regenta grodzkiego do archiwum, ciągle znajdującego się na zamku ${ }^{28}$. Chodziło bowiem o uniemożliwienie dokonywania jakichkolwiek wpisów poza godzinami urzędowania.

Pół roku później sejmik ten wyraził zgodę na przeniesienie kancelarii grodzkiej $\mathrm{z}$ dotychczasowego pomieszczenia na zamku do kamienicy mieszczanina poznańskiego Marcina Ludyka ${ }^{29}$, zwalniając go $\mathrm{w}$ zamian za to $\mathrm{z}$ obowiązku uiszczania podatku czopowego i szelężnego ${ }^{30}$. Jednocześnie zobowiązano regenta grodzkiego, którym był wojski inowrocławski Franciszek Żegocki, do zabezpieczenia archiwum grodzkiego w miejscu bardziej odpowiednim, w którym mogły być lepiej chronione. Uchwalono też wykorzystanie na ten cel odpowiednich kwot pochodzących z czopowego i szelężnego ${ }^{31}$.

W roku 1714 stan pomieszczeń archiwalnych na zamku poznańskim pogorszył się do tego stopnia, że dalsze przechowywanie w nich akt nie było już możliwe. Musiano znaleźć nowe lokum na terenie miasta, co wcale nie było łatwe, gdyż prawdopodobnie sejmik nie dysponował funduszami umożliwiającymi wynajęcie całej kamienicy. Znacznie tańsze było umieszczenie akt grodzkich w dobrze zabezpieczonym budynku ratusza. W tym celu zobowiązano marszałka sejmiku do zwrócenia się do kanclerza koronnego, żeby w imieniu króla nakazał władzom miejskim zgodę na takie rozwiązanie ${ }^{32}$. Tego pomysłu nie udało się jednak zrealizować, dlatego sejmik zalecił załatwienie tej sprawy wspomnianemu regentowi grodzkiemu Żegockiemu, czyli najbardziej odpowiedniej osobie i faktycznemu kierownikowi kancelarii ${ }^{33}$. Regent ten miał przewieźć akta do bardziej odpowiedniego pomieszczenia, na co wyasygnowano 500 zł z czopowego i szelężnego ${ }^{34}$.

Wobec niezrealizowania pomysłu o umieszczeniu akt grodzkich w ratuszu poznańskim musiano poszukiwać dla nich miejsca w prywatnym domu. W końcu udało się wynająć pomieszczenia w kamienicy benedyktynek chełmińskich, płacąc im z tego tytułu 200 zł rocznie z czopowego i szelężnego, tak długo, jak długo miały być wykorzystywane do przechowywania akt $\mathrm{t}^{35}$. Umieszczenie ich w tej kamienicy doraźnie rozwiązało problem, ale rezygnacja z przechowywania całej dokumentacji na zamku w okresie późniejszym okazała się ostatecznie mało racjonalna. Oznaczała bowiem konieczność rezygnacji z wykorzystywania budynku, który od wieków symbolizował władzę króla i stanowił siedzibę starosty generalnego jako jego przedstawiciela.

W kolejnych latach sejmik starał się wyasygnować fundusze na remont pomieszczeń archiwalnych na zamku. W roku 1720 przeznaczył na nią sumy należne z tytułu czopowego, których nie przekazał cech piwowarów, zastrzegając, że gdyby one nie wystarczyły, to resztę pieniędzy powinien wyasygnować starosta generalny

28 Akt. sej. poz. 1696-1732, s. 626.

${ }^{29}$ M. Zw i er zy kow s ki, Szlacheckie instytucje sadowe..., s. 240.

${ }^{30}$ Akt. sej. poz. 1696-1732, s. 645 (laudum z 7 V 1711).

31 Ibidem.

32 Ibidem, s. 763 (laudum z 16 IX 1714). M. Zwierzykowski, Problematyka archiwalna w uchwałach sejmiku województw poznańskiego i kaliskiego..., s. 43.

${ }_{33}$ M. Z wi er zy k ow s k i, Sejmikowe próby remontu..., s. 281.

${ }^{34}$ Akt. sej. poz. 1696-1732, s. 776 (laudum z 2 X 1714).

35 Ibidem, s. 786 (laudum z 7 I 1715). 
wielkopolski ${ }^{36}$. Rok później prace restauracyjne, polegające na przystosowaniu nowego pomieszczenia ,sklepu” na potrzeby archiwalne, były już na tyle zaawansowane, że komisarzowi wojewódzkiemu Aleksandrowi Gorzeńskiemu obiecano 8 tys. zł na pokrycie wydatków z tym związanych ${ }^{37}$.

W latach 30. akta grodzkie poznańskie oraz ziemskie znalazły schronienie w poznańskim klasztorze Dominikanów i z tego powodu sejmik średzki obradujący w roku 1735 przeznaczył 1500 zł jako rekompensatę za długoletnie przechowywanie $^{38}$. Nieco później pojawiła się również potrzeba remontu pomieszczeń zajmowanych przez kancelarie grodzkie, więc sejmik średzki obradujący w roku 1748 przeznaczył dla większych kancelarii poznańskiej i kaliskiej po 12 tys. zł, a mniejszym (gnieźnieńskiej, konińskiej, kościańskiej, pyzdrskiej i wschowskiej) zamierzał podarować po 1,5 tys. $\mathrm{z}^{39}$. Tego postanowienia jednak nie zrealizowano, dlatego w roku 1755 je reasumowano, obniżając kwoty przeznaczone dla mniejszych kancelarii do $500 \mathrm{zt}^{40}$. W roku 1760 akta grodzkie już były przechowywane na zamku poznańskim, ale zajęły go oddziały rosyjskie, które znalazły się tam w wyniku działań przeciw wojsku pruskiemu w czasie wojny siedmioletniej. $\mathrm{Na}$ dziedzińcu zamkowym rozmieściły proch i amunicję $e^{41}$, co zagrażało bezpieczeństwu dokumentacji. Rosjanie okupowali go jeszcze w roku następnym, co wywoływało wielkie niezadowolenie szlachty wielkopolskiej ${ }^{42}$.

W złych warunkach przechowywano także akta grodzkie kaliskie. Pomieszczenia miejscowego grodu, czyli tzw. sklep, wymagały naprawy i ,nakrycia”. W roku 1711 sejmik polecił więc dokonanie potrzebnych napraw, na które tak jak w przypadku grodu poznańskiego przeznaczyć miano dochody z czopowego i szelężnego, którymi mógł dysponować sejmik ${ }^{43}$. W końcu akta grodzkie musiano zabezpieczyć w ratuszu kaliskim, a więc uczyniono to, czego nie udało się dokonać w Poznaniu ${ }^{44}$. Dziewięć lat później problem restauracji pomieszczeń archiwalnych w grodzie kaliskim w dalszym ciągu nie był rozwiązany i szlachta musiała przeznaczyć na ten cel znaczną kwotę 5 tys. zł z sum czopowego i szelężnego pobieranych z miasta ${ }^{45}$. Po dokonaniu remontu ,sklepu" akta miały tam być ponownie przeniesione pod nadzorem miejscowego regenta grodzkiego ${ }^{46}$. Akta ziemskie kaliskie przechowywano w roku 1748 w jednym z pomieszczeń kaliskiego klasztoru Kanoników Regularnych, które wymagało remontu, dlatego załatwienie tej sprawy powierzono miejscowemu regentowi ziemskiemu ${ }^{47}$. W latach 50 . akta te po raz kolejny zmieniły miejsce

\footnotetext{
36 Ibidem, s. 895 (laudum z 20 IV 1720).

37 Ibidem, s. 937 (laudum z 24 III 1721).

38 Akt. sej. poz. 1733-1763, s. 201 (13 IX 1735)

39 Ibidem, s. 442-443 (laudum z 11 IX).

40 Ibidem, s. 546 (laudum z 16 IX).

41 Ibidem, s. 626 (laudum 25 VIII).

42 Ibidem, s. 692 (laudum z 15 IX).

${ }^{43}$ Akt. sej. poz. 1696-1732, s. 645 (laudum z 7 V 1711).

44 Ibidem, s. 1006 (laudum z 17 VIII 1726).

45 Ibidem.

46 Ibidem.

47 Akt. sej. poz. 1733-1763, s. 443 (laudum z 11 IX 1748).
} 
przechowywania i znajdowały się w miastach powiatowych województwa, ale tego rozwiązania nie uznawano za dobre, dlatego sejmik z roku 1755 polecił przewieźć je do zamku kaliskiego i uczynił za to odpowiedzialnym regenta ziemskiego ${ }^{48}$.

Szlachta krakowska znacznie rzadziej interesowała się sprawami przechowywania akt ze względu na zdecydowanie lepszy stan zamku wawelskiego, w którym przechowywano akta grodzkie. Zupełnie inaczej wyglądała sytuacja akt ziemskich krakowskich, które nie miały stałego archiwum i były przechowywane w różnych miejscach. W roku 1606 w instrukcji dla posłów wybranych na sejmiku umieszczono polecenie, aby dla zabezpieczenia ksiąg ziemskich, znajdujących się w kilku skrzyniach, wielkorządca krakowski przeznaczył osobne pomieszczenie („sklep”) na zamku ${ }^{49}$. Realizacja tego postulatu nie była prosta, ponieważ zamek zarządzany był przez urzędników podległych królowi i zupełnie niezależnych od sejmiku. Posłowie krakowscy doprowadzili do ustanowienia w roku 1647 konstytucji sejmowej „Sądy ziemskie krakowskie” ${ }^{50}$, na mocy której na zamku krakowskim miano wydzielić odrębne pomieszczenie (,sklep”) dla przechowywania akt ziemskich ${ }^{51}$.

Ale tego postanowienia nie udało się wykonać w ciągu dwudziestu lat. W tej sytuacji w roku 1668 sejmik proszowicki zobowiązał swoich posłów, aby skłonili wielkorządcę krakowskiego do realizacji konstytucji sejmowej i wygospodarowania osobnego pomieszczenia na akta ziemskie, ponieważ „sklep” grodzki był zapełniony aktami $^{52}$. W przypadku sprzeciwu wielkorządcy posłowie mieli zwrócić się do króla, aby wykonał postanowienie sejmu ${ }^{53}$. Sejmik proszowicki zajął się też problemem przechowywania akt ziemskich czchowskich, które były zabezpieczone w skrzyniach i złożone u proboszczów czchowskiego i jakubkowickiego, utrudniających do nich dostęp, co wywołało protesty szlachty ${ }^{54}$. Szlachta zgromadzona na sejmiku zdecydowanie domagała się ukarania obu duchownych ${ }^{55}$ niewłaściwie pojmujących obowiązki, których się podjęli.

Najwięcej uwagi sprawom należytego przechowywania akt grodzkich i ziemskich poświęcił sejmik województwa ruskiego obradujący w Wiszni. Już w roku 1590 postulowano w czasie jego obrad wyznaczenie stałego pomieszczenia przeznaczonego nie tylko na posiedzenia sądów ziemskich lwowskich i przemyskich, ale też na zgromadzoną i wytworzoną przez nie dokumentację ${ }^{56}$. Akta lwowskie były przechowywane w oddzielnym pomieszczeniu (,sklepie”) w Zamku Niskim i zostały zalane przez wodę w czasie powodzi (w latach 1653 i 1658). Dlatego

48 Ibidem, s. 546 (laudum z 16 IX).

49 Akta sejmikowe województwa krakowskiego (dalej: A.sej.kr), wyd. S. Kutrzeba, t. I, Kraków 1932, s. 280 (16 II 1606).

50 Volumina legum, t. IV, f. 109.

${ }^{51}$ A.sej.kr, t. III (1661-1673), wyd. A. Przyboś, Wrocław 1959, s. 221.

52 Ibidem.

53 Ibidem.

${ }^{54}$ A.sej.kr, t. V (1681-1696), wyd. A. Przyboś, Wrocław 1984, s. 23 (laudum z 16 XII 1682).

55 Ibidem.

${ }^{56}$ Akta grodzkie i ziemskie z czasów Rzeczypospolitej Polskiej z archiwum tak zwanego bernardyńskiego we Lwowie (dalej: Agz), t. XX (Lauda sejmikowe wiszeńskie 1572-1648), wyd. A. Pro ch a s ka, Lwów 1909, nr 33, s. 89. 
w roku 1665 na sejmiku ruskim zgłoszono propozycję przeznaczenia na potrzeby archiwum ziemskiego położonej przy ulicy Dominikańskiej kamienicy, użytkowanej przez spadkobierców kasztelana sanockiego Zygmunta Fredry, która została zajęta w drodze egzekucji sądowej z tytułu niezapłaconych przez nich podatków ${ }^{57}$.

Niedługo potem zakupiono ten budynek i przekazano do użytkowania sądu ziemskiego, a sejmik wykazywał wiele troski, aby jedno z jego pomieszczeń dostosować do potrzeb archiwalnych, przeznaczając $w$ roku 1682 sumę 3 tys. zł na wymurowanie odpowiedniego pomieszczenia (,sklepu") ${ }^{58}$. Mimo tego stan pomieszczenia nie był zadowalający i w kolejnych latach na jego wyposażenie sejmik uchwalił dalsze sumy $^{59}$. Dwanaście lat później sytuacja lokalowa archiwum ziemskiego nie polepszyła się. Ponieważ miejsce do przechowywania akt było całkowicie zrujnowane, sejmik zobowiązał wybranych posłów, by doprowadzili do odzyskania kamienicy od spadkobierców wspomnianego już kasztelana sanockiego ${ }^{60}$.

W drugiej połowie XVIII wieku kamienica będąca siedzibą kancelarii ziemskiej i archiwum została wyremontowana. Była jednak obciążona długami, w wyniku czego wierzyciele, niejaki Czergowski oraz franciszkanie lwowscy, zaczęli upominać się o zwrot należności. Z tego powodu w 1766 roku sejmik gospodarczy powołał komisję, w której skład weszli pisarz grodzki lwowski Stefan Horodyński oraz miejscowy regent ziemski Jan Ludwik Dębowski. Jednocześnie nadał im prawo do rozpatrywania pretensji wierzycieli, zastrzegając jednak, że ich rozstrzygnięcia będą wymagały aprobaty sejmiku ${ }^{61}$. W tym roku kamienica została oddana w użytkowanie pisarzowi ziemskiemu lwowskiemu Andrzejowi Roli Janickiemu, z wyłączeniem pomieszczeń przeznaczonych na potrzeby sądu ziemskiego ${ }^{62}$. Pisarz ten obiecał szlachcie zgromadzonej na sejmiku rozliczenie z dochodów uzyskanych z tej kamienicy oraz wydatków dokonanych na jej utrzymanie ${ }^{63}$.

Utrzymywanie takiego budynku w należytym stanie pociągało jednak za sobą duże wydatki ze względu na postępującą degradację jego stanu fizycznego. Budująca sąsiednią kamienicę mieszczka Szulcowa na wzniesienie ściany swojego budynku, w istotnym stopniu wzmacniającej kamienicę ziemiańską, wydała 3063 zł, z których połowę musiała pokryć szlachta lwowska ${ }^{64}$. W czasie prac budowlanych musiano wzmocnić też fundamenty ściany budynku kancelaryjnego, co rodziło dodatkowe koszty związane z rekompensatami, których domagała się wymieniona

57 Ibidem, t. XXI (Lauda sejmiku wiszeńskiego 1648-1673), oprac. A. Prochas ka, Lwów 1911, s. 408; P. D ą b k ow s k i, Księgi sądowe lwowskie..., s. 13.

58 Agz, t. XXII (Lauda sejmiku wiszeńskiego 1673-1732), oprac. A. Prochaska, Lwów 1914, s. 150; P. D ą b k ow s k i, Księgi sądowe lwowskie..., s. 14.

${ }_{59}$ Agz, t. XXII (Lauda sejmiku wiszeńskiego 1673-1732), oprac. A. Prochaska, Lwów 1914,

s. 171; P. Dą b k ow s k i, Księgi sądowe lwowskie..., s. 14.

${ }^{60}$ Agz, t. XXII, s. 408, pkt 33.

${ }^{61}$ Ibidem, t. XXIII, s. 526-527, pkt 3 (laudum z 16 IX 1766).

62 Ibidem. Brak wzmianki o tym fakcie w pracy P. Dąbkowskiego, Księgi sądowe lwowskie.., s. $19-20$.

${ }^{63}$ Agz, t. XXIII, s. 526-527, pkt 3 (laudum z 16 IX 1766).

${ }^{64}$ Ibidem, s. 575, pkt 5 (laudum sejmiku z 14 IX 1768). Pominął ten szczegół P. Dąbk owski, Księgi sądowe lwowskie..., s. 20. 
mieszczka ${ }^{65}$. Z powodu narastających kosztów lwowski sejmik gospodarski w roku 1768 powołał trzyosobową komisję, która miała dokonać wyceny wartości budynku i sprzedać ją mimo że wcześniej wydzierżawiono ją na trzy lata sędziemu grodzkiemu lwowskiemu Hordyńskiemu ${ }^{66}$. Dochody z tej kamienicy pomniejszone były o sumę $70 \mathrm{zł}$ stanowiącą procent należny franciszkanom lwowskim z tytułu legatu 1000 zł dokonanego w 1666 roku przez dawnego właściciela budynku kasztelana lwowskiego Andrzeja Maksymiliana Fredrę ${ }^{67}$. Dalsze postępowanie sejmiku w tej sprawie przerwał pierwszy rozbiór Polski i włączenie większości ziem województwa ruskiego do monarchii habsburskiej.

Sejmik wiszeński zajmował się też stanem akt żydaczowskich. W 1680 roku miejscowy zamek był bardzo zniszczony, dlatego szlachta przeznaczyła na jego restaurację 2 tys. zł z podatku czopowego, którą sumę wykorzystać miał miejscowy starosta $^{68}$. Odbudowa zamku postępowała od fundamentów, więc pieniądze te szybko zostały wydane na opłacenie niezbędnych robót. W roku następnym na dokończenie prac restauracyjnych przeznaczono kolejne 2 tys. z $\mathrm{z}^{69}$. Zamek żydaczowski był położony $\mathrm{z}$ dala od miasta, dlatego szlachta postanowiła wznieść budynek kancelarii w bardziej dogodnym miejscu. W 1685 roku sejmik przeznaczył 300 zł z czopowego ${ }^{70}$, co było jednak kwotą niewystarczająca i $\mathrm{w}$ zasadzie nie rozwiązywało problemu. Ostatecznie dwa lata później zamek żydaczowski był już odrestaurowany, głównie dzięki wsparciu finansowemu starosty i kasztelana kijowskiego Jerzego Dzieduszyckiego. Szlachta obecna na sejmiku województwa ruskiego postanowiła wystawić jeszcze wieżę i murowane pomieszczenie na księgi, przeznaczając na ten cel 2 tys. $\mathrm{zł}^{71}$. Jednocześnie dodała $100 \mathrm{zł}$ na lokal kancelaryjny ${ }^{72}$.

W pomieszczeniu przeznaczonym na dokumentację miano gromadzić zarówno akta grodzkie, jak i ziemskie, co stanowiło ewenement, gdyż na innych terenach z reguły starano się przechowywać je w oddzielnych budynkach. W roku 1690 na dokończenie murowania "sklepu” i zabezpieczenie go żelaznymi drzwiami oraz okiennicami wyasygnowano kolejne 3 tys. zł z czopowego ${ }^{73}$. W końcu udało się ukończyć budowę tego „sklepu”, ale dziesięć lat później, w roku 1699, był on już zniszczony, wobec czego szlachta poleciła wyasygnować 5 tys. zł na jego odbudowę ${ }^{74}$. W 1752 roku budynek kancelarii grodzkiej żydaczowskiej był już jednak zrujnowany, co wywoływało obawę ziemian tego powiatu o bezpieczeństwo

\footnotetext{
${ }^{65}$ Ibidem.

${ }^{66}$ Ibidem.

${ }^{67}$ Ibidem.

${ }^{68}$ Agz, t. XXII, s. 118-119, pkt 6 (laudum z 9 IX 1680).

${ }^{69}$ Ibidem, s. 139, pkt 6 (laudum z 15 VII 1681).

${ }^{70}$ Ibidem, s. 196, pkt 12 (laudum z 11 IX 1685); P. Dąbkowski, Z przeszłości ksiag grodzkich i ziemskich żydaczowskich..., s. 235.

${ }^{71}$ Agz, t. XXII, s. 199, pkt 12 (laudum z 16 XII 1687).

${ }^{72}$ Ibidem.

${ }^{73}$ Ibidem, s. 237, pkt 19 (laudum z 23 IX 1690); P. Dąbkowski, Z przeszłości ksiag grodzkich i ziemskich żydaczowskich..., s. 235.

${ }^{74}$ Agz, t. XXII, s. 329, pkt 13 (laudum z 1 VI 1699); P. D ą b k ow s ki, Z przeszlości ksiagg grodzkich i ziemskich żydaczowskich..., s. 236.
} 
znajdujących się w nim ksiąg, dlatego ziemianie lwowscy, popierając prośbę szlacheckich mieszkańców powiatu żydaczowskiego, postanowili przeznaczyć na remont budynku pewne sumy z podatków szelężnego i czopowego, które miały być pobierane $\mathrm{w}$ roku następnym ${ }^{75}$. Ostatecznie na remont budynku kancelarii i wzniesienie pomieszczenia dla przechowywania akt przypadła kwota 2 tys. zł, którą miał wykorzystać podstarości i sędzia grodzki żydaczowski Worcell ${ }^{76}$.

W Przemyślu problem stałej siedziby dla akt ziemskich udało się rozwiązać na początku lat 40 . XVII wieku, kiedy za sumę 3 tys. zł pochodzącą w większej części $\mathrm{z}$ retent poborowych oraz $\mathrm{z}$ pieniędzy pozostałych $\mathrm{w}$ dyspozycji szafarza przemyskiego zakupiono kamienicę u franciszkanów przemyskich ${ }^{77}$. Tam były złożone $\mathrm{w}$ jednym z pomieszczeń, a pieczę nad nimi sprawował pisarz ziemski przemyski, który miał też pobierać czynsz pochodzący z wynajmu pozostałych pomieszczeń i zajmować się utrzymywaniem całego budynku w należytym stanie ${ }^{78}$. W 1714 roku pomieszczenia kancelarii ziemskiej wymagały remontu, więc sejmik przeznaczył na przeprowadzenie najpilniejszych prac restauracyjnych kwotę 600 zł z dochodów pochodzących z czopowego ${ }^{79}$.

W połowie XVIII wieku kamienica ziemska w Przemyślu wymagała remontu, którego przeprowadzenie sejmik wiszeński z 1751 roku zlecił sędziemu ziemskiemu Antoniemu Drohojowskiemu, przeznaczając na ten cel kwotę 6 tys. $z^{80}$. Potem kamienicę użytkował Szczepan Józef Dwernicki, łowczy przemyski oraz pisarz grodzki przemyski ${ }^{81}$. W roku 1761 wydał on na prace remontowe w tym budynku ponad 3600 zł, podczas gdy obradujący wcześniej sejmik przeznaczył na ich przeprowadzenie tylko 3000 zł. Nadwyżki wydatku pisarzowi nie zwrócono, uzasadniając tę decyzję faktem posiadania przez niego prawa do użytkowania budynku ${ }^{82}$, co dawało możliwość uzyskania dochodów rekompensujących wydatki. Szlachta przemyska w roku 1755 zainteresowała się także stanem akt ziemskich przeworskich przechowywanych w klasztorze Bernardynów w Przeworsku, które wymagały „lepszej konserwacji” ${ }^{\prime 83}$. Zaleciła też skarbnikowi przemyskiemu Antoniemu Konopackiemu

75 Agz, t. XXIII, s. 294 (uchwała ziemian lwowskich z 13 III 1752). Brak informacji o niej we wspomnianej pracy P. Dąbkowskiego.

${ }^{76}$ Agz, t. XXIII, s. 313, pkt 13 (uchwała ziemian lwowskich z 13 III 1752). Także tej informacji nie ma w cytowanym wyżej opracowaniu P. Dąbkow s kiego.

77 Agz, t. XXI, s. 453 (instrukcja dla posłów z 9 VII 1641); P. Dą b k ow s ki, Księgi sądowe przemyskie i przeworskie..., s. 14.

78 Agz, t. XXI, s. 453.

79 Ibidem, t. XXI, s. 578-579; P. Dą b k ow s k i, Księgi sądowe przemyskie i przeworskie...

${ }^{80}$ Agz, t. XXIII, s. 290; P. Dą b k ow s k i, Księgi sądowe przemyskie i przeworskie.., s. 22.

${ }^{81}$ Agz, t. XXIII, s. 424, pkt 9. P. Dą b kow ski (Księgi sądowe przemyskie i przeworskie..., s. 22) błędnie określił go jako pisarza ziemskiego przemyskiego. Pomyłkę tę zauważył K. Przy boś w swoim opracowaniu Urzędnicy województwa ruskiego XIV-XVIII wieku (ziemie halicka, lwowska, przemyska i sanocka). Spisy, Wrocław 1987, s. 216, nr 1826.

${ }^{82}$ Agz, t. XXIII, s. 424 (uchwały ziemian przemyskich z 1 II 1762). P. Dąbkowski nie wspomniał o tym fakcie w swojej pracy o księgach sądowych przemyskich. Idem, Księgi sądowe przemyskie i przeworskie..., s. 24-25.

${ }^{83}$ Agz, t. XXIII, s. 325, pkt 6. Brak informacji o tym fakcie w pracy P. Dą b kow s kie g o, Księgi sadowe przemyskie i przeworskie $w$ dawnej Polsce... 
i jednemu z miejscowych komorników ziemskich sprawdzenie stanu skrzyni, w której akta były przechowywane ${ }^{84}$. W przypadku złego jej stanu, niegwarantującego bezpieczeństwa złożonych w niej akt, poleciła sporządzenie nowej skrzyni ${ }^{85}$.

Sejmik wiszeński również przejawiał zainteresowanie stanem pomieszczeń, w których przechowywano akta sanockie. W roku 1665 podjął uchwałę w sprawie zbudowania „dworu” dla sądu ziemskiego sanockiego oraz murowanego „sklepu” dla przechowywanych przez niego ksiąg ziemskich ${ }^{86}$. Tego postulatu szlachcie sanockiej nie udało się jednak zrealizować. W 1685 roku sądy ziemskie odbywały się w ratuszu sanockim i w ich pracy bardzo przeszkadzali „smolacy”, czyli żołnierze powołani przez sejmik do utrzymywania porządku na terenie ziemi. Przetrzymywali oni pojmanych przestępców właśnie w tym budynku, w wyniku czego niszczały przeznaczone na przechowywanie akt pomieszczenia, które wykorzystywano jako tymczasowy aresz ${ }^{87}$. $Z$ tego powodu sejmik zalecił znalezienie innego miejsca na więzienie dla przestępców, w tym nawet karczmy położonej na przedmieściu ${ }^{88}$.

Zainteresowanie warunkami zabezpieczenia akt wykazywał także sejmik halicki. $\mathrm{W}$ trosce o polepszenie stanu przechowywania akt ziemskich, zdecydowanie gorszego niż w przypadku akt grodzkich, poparł w roku 1763 inicjatywę chorążego halickiego Antoniego Marcina Borysławskiego. Zobowiązał się on do darowania placu na wystawienie kancelarii ziemskiej w bezpośrednim sąsiedztwie należących do niego gruntów ${ }^{89}$. Budynku kancelarii nie udało się wybudować, przeszkodził w tym rozbiór Rzeczypospolitej i włączenie tej części województwa ruskiego do monarchii austriackiej.

Zewnętrzne okoliczności sprawiły, że więcej troski o stan akt sądów szlacheckich musiała okazać szlachta chełmska. Początkowo interesował ją stan akt ziemskich, które w przeciwieństwie do grodzkich nie miały stałego miejsca przechowywania. Sejmik obradujący w 1636 roku postanowił zobowiązać starostę chełmskiego Hieronima Jełowieckiego, aby doprowadził do zbudowania odpowiedniego pomieszczenia (,sklepu”) w ratuszu chełmskim. Przeznaczył na to kwotę 1335 zł i 16 gr pozostałą z podatku ośmiu poborów, dzięki któremu zamierzano uregulować należności wobec wojska ${ }^{90}$. Do realizacji tej uchwały jednak nie doszło, gdyż w roku 1637 spłonął kościół farny, w którym szlachta chełmska z reguły odbywała sejmiki. Za radą kapituły chełmskiej wspomniany sejmik, który zebrał się w 1639 roku, postanowił przeznaczyć wymienioną wyżej kwotę na odbudowę świątyni i wymurowanie w niej

84 Ibidem.

85 Ibidem.

${ }^{86}$ Agz, t. XXI, s. 408, pkt 33; P. D ą b kow s ki, Palestra i księgi sanockie..., s. 19.

${ }^{87}$ Agz, t. XXII, s. 187, pkt 78 (laudum z 10 VII 1685). Brak informacji o tym fakcie w cytowanej pracy P. Dąbkowskiego.

88 Ibidem.

${ }^{89}$ Ibidem, t. XXV, s. 565, nr 7 (laudum z 13 IX 1763). Nie wspomniał o tym P. Dąbkowski w swojej pracy Palestra i księgi sądowe trembowelskie za czasów polskich, „Przegląd Prawa i Administracji” 1919, r. 44, z. 1, s. 1-57.

90 APL, Agch, RMO, syg. 61, k. 261v (laudum z 9 XII). Zob. też Akta sejmikowe ziemi chetmskiej 1572-1668, oprac. W. B on dyra, H. Gmiterek, J. Ternes, Lublin 2013, s. 187. 
„sklepu” dla zabezpieczenia ksiąg ziemskich ${ }^{91}$. Do realizacji tego postanowienia jednak nie doszło.

Jak już wspomniano, w okresie zagrożenia kozacko-tatarskiego akta grodzkie i ziemskie chełmskie przewieziono do Zamościa i umieszczono w tamtejszym ratuszu. W roku 1654 sejmik chełmski zadeklarował zapłatę za to rajcom zamojskim w wysokości 100 zł, potwierdzając to w uchwale podjętej dwa lata później ${ }^{92}$. Lokal, w którym przechowywano akta, potrzebny był miastu do złożenia broni, dlatego jego władze zwróciły się z prośbą do sejmiku o opróżnienie tego pomieszczenia ${ }^{93}$. Z kłopotu starał się wybawić szlachtę chełmską rektor Akademii Zamojskiej Bazyli Rudomicz, ofiarując odpowiedni lokal w budynku szkoły. W roku 1665 sejmik chełmski zgodził się na propozycję rektora, zobowiązując jednocześnie pisarza ziemskiego chełmskiego do przewiezienia akt ziemskich z ratusza do „sklepu” w Akademii ${ }^{94}$.

To wygodne dla miasta rozwiązanie nie zostało zrealizowane ${ }^{95}$. W 1668 roku rajcy zamojscy ponowili prośbę dotyczącą przeniesienia akt ziemskich i grodzkich do pomieszczenia w budynku Akademii, co dowodzi, że dokumentacja nadal pozostawała w budynku ratusza ${ }^{96}$. Za przechowywanie akt sejmik obiecał płacić rektorowi Akademii $100 \mathrm{zł}$ rocznie z dochodów pochodzących z podatku czopowego. $\mathrm{W}$ roku 1673 akta te znajdowały się już w ratuszu zamojskim, gdyż szlachta zgodziła się na opłacenie kosztów przechowywania we wspomnianej kwocie za ten rok i następny ${ }^{97}$. Przechowywano je tam w latach 80 . XVII wieku, do roku $1690^{98}$.

Na uwagę zasługuje też fakt zainteresowania stanem zabezpieczenia akt grodzkich, tak jak to się stało w innych województwach i ziemiach. Bezpośrednio byli za nie odpowiedzialni starostowie, ale szlachta, dążąc do zapewnienia bezpieczeństwa zawartym w aktach dowodom prawnym, świadomie wkraczała w kompetencje wymienionych urzędników królewskich. Dowód tego stanowi instrukcja dla posłów wybranych na sejmiku chełmskim w dniu 21 sierpnia 1730 roku. Polecono im, by zobowiązali starostów do większej dbałości o pomieszczenia kancelaryjne i pomieszczenia, w których przechowywano księgi urzędowe ${ }^{99}$.

Dowodów troski o akta dostarczają także uchwały sejmiku sieradzkiego. W roku 1679 księgi grodzkie były złożone w kościele farnym, w którym część z nich zbutwiała. Z tego powodu szlachta uchwaliła przeniesienie akt do kościoła

91 APL, Agch, RMO, syg. 61, k. 262 (laudum z 25 VIII); Akta sejmikowe ziemi chetmskiej..., s. 206-207.

92 APL, Agch, RMO, syg. 74, k. 1210 (laudum z 2 X 1656); Akta sejmikowe ziemi chetmskiej..., S. 408.

93 R. Jop, op. cit., s. 128.

94 APL, Agch, RMO, syg. 70, k. 310 (laudum z 14 IX 1665); Akta sejmikowe ziemi chetmskiej..., S. 553 .

95 Ibidem.

96 Ibidem, Akta grodzkie krasnostawskie, RMO, syg. 5, k. 952 (laudum z 15 X 1668); Akta sejmikowe ziemi chetmskiej..., s. 689.

97 Ibidem, Agch, RMO, syg. 93, k. 371v (laudum z 10 IX 1674).

98 Ibidem, syg. 111, k. 458v (laudum z 19 VI 1690).

99 J. Łos ow ski, op. cit., s. 150. 
dominikanów, w którym jednak nie miały lepszych warunków przechowywania ${ }^{100}$. W roku 1692 wojski sieradzki Karol Łopatecki poinformował szlachtę o złym stanie akt, co skłoniło ją do poszukiwania bezpieczniejszego pomieszczenia dla dokumentacji. Rezultaty tych starań nie są jednak znane ${ }^{101}$. W czasie wojny północnej sejmik wydelegował swoich przedstawicieli w celu uzyskania zgody na zabezpieczenie akt grodzkich i ziemskich sieradzkich w klasztorze Paulinów na Jasnej Górze, co nie przyniosło rezultatów. Dalsze kroki podejmowane w roku 1704 w celu ukrycia akt przed nieprzyjacielem okazały się nieskuteczne i część akt została spalona. Później wielokrotnie przewożono je do Sieradza, Piotrkowa i Bukowca ${ }^{102}$.

Dbałość o sprawy lokali, w których przechowywano akta sądowe, przejawiała także szlachta kujawska. W 1707 roku na sejmiku radziejowskim starosta brzesko-kujawski Andrzej Głębocki zgłosił postulat wynagrodzenia dla dominikanów za kilkuletnie przechowywanie akt sądowych, załatwienie tej sprawy odłożono jednak na później ${ }^{103}$. W czasie szerzącej się zarazy w roku 1710 akta grodzkie radziejowskie przewieziono z tego miasta do Czołowa. Jednocześnie zezwolono pisarzowi grodzkiemu radziejowskiemu Wojciechowi Jasieńskiemu na przechowywanie „suscept” i „ekspedycji” w swojej posiadłości w Opatowicach ${ }^{104}$. Zwolnienie miasta Inowrocławia z połowy czopowego uchwalono w roku 1722, ponieważ w ratuszu przechowywano akta ziemskie i grodzkie, a ze względu na zły stan wymagał on remontu ${ }^{105}$.

Szlachta Wielkiego Księstwa Litewskiego okazywała zainteresowanie sprawami wznoszenia budynków archiwalnych, chociaż na ten temat wiadomo znacznie mniej niż o sytuacji w Koronie. Na sejmie litewskim w Grodnie w 1568 roku przedstawiciele szlachty mińskiej oraz na sejmie lubelskim w roku 1569 reprezentanci powiatu wiłkomirskiego domagali się wyznaczenia placów, na których miano wznieść budynki na potrzeby sądów ziemskich i ich archiwów ${ }^{106}$. W roku 1590 i 1610 na sejmikach nowogródzkich uchwalono specjalny podatek na budowę domu sądowego ${ }^{107}$. Podobne podatki ustanowiono na sejmikach wołkowyskim i słonimskim ${ }^{108}$.

W XVIII wieku dążenie do polepszenia lokalowych warunków pracy szlacheckich kancelarii oraz przechowywania akt swojego powiatu wykazała szlachta trocka. W roku 1766 na miejscowym sejmiku zgromadzeni uczestnicy podjęli uchwałę o opodatkowaniu się na ten cel po pół złotego od dymu ${ }^{109}$. Ewentualna nadwyżka miała być

${ }^{100}$ A. Burkietowicz, op. cit., s. 58-59.

101 Ibidem.

102 Ibidem.

103 Lauda i instrukcje 1700-1733, s. 140.

104 Ibidem, s. 191; W. Ch or ąży c zew s ki, K. Sy ta, Stosunek szlachty polskiej..., s. 6-7.

105 Lauda i instrukcje 1700-1733, , s. 363; W. Chorążyczewski, K. Sy ta, Stosunek szlachty polskiej..., s. 18.

${ }^{106}$ D. Vilimas, Lietuvos Didžiosios Kunigaikštystès žemès teismo sistemos formavimasis (15641588), Vilnius 2006, s. 89.

107 A. Radaman, Uchvalenne mâscovych podatkaŭ na sojmikach ì šljacheckich z'ezdach Novagarodskaga vâ̂vodstva VKL u drugoj palove XVI - pačatky XVII st., „Belaruski Gistaryčny Časopis” 2013, nr 9, s. 28.

108 Ibidem.

109 A.B. Zakrzews k i, Budowa archiwów..., s. 111-118; idem, Sejmiki Wielkiego Księstwa Litewskiego XVI-XVIII w..., s. 200. 
przeznaczona na siedzibę kancelarii ziemskiej ${ }^{110}$. Mimo tego budynek nie powstał. Dopiero po wzniesieniu przez dominikanów klasztoru w Trokach, na który szlachta przeznaczyła składkę w wysokości 15 gr od dymu, postanowiono zobowiązać ich do zbudowania budynku kancelarii grodzkiej i ziemskiej, archiwum, wieży „cywilnej” oraz szopy do sejmikowania, na co wyrazili zgodę ${ }^{111}$. Realizacja tego zobowiązania przebiegała jednak z oporami. Ostatecznie udało się urządzić archiwum w izbie na piętrze bliżej nieokreślonego budynku ${ }^{12}$. Stało się to dopiero w 1793 roku $^{113}$.

\section{POSTULATY DOTYCZACEE REWIZJI AKT, ICH PORZĄDKOWANIA ORAZ EWIDENCJONOWANIA}

Stan archiwów grodzkich i ziemskich niejednokrotnie pozostawiał wiele do życzenia. Wynikało to czasem z niedbałości personelu kancelaryjnego, który koncentrował się na załatwianiu spraw bieżących. Zajmował się sporządzaniem dokumentacji, głównie protokołowaniem obrad sądowych, przyjmowaniem zeznań stron oraz odpisywaniem różnego rodzaju manifestacji (tzw. kopii), przepisywaniem brudnopisów na czysto oraz dokonywaniem odpisów uniwersałów przesyłanych do urzędu grodzkiego w celu rozesłania ich do miast czy też parafii. Urzędnicy kierujący kancelarią zobowiązani byli również do odpowiedniego nadzoru nad podległym personelem, aby dbał o regularne formowanie jednostek należących do poszczególnych serii aktowych, ich oprawę oraz uzupełnianie ewidencji przechowywanych materiałów.

Kierownictwo kancelarii było też odpowiedzialne za utrzymywanie porządku dokumentacji w samej kancelarii lub w pomieszczeniu archiwalnym. Najważniejszą przyczyną nieporząaków było zaniedbywanie porządkowania narastających kopii oraz przepisywania ich na czysto (indukowania), a nawarstwianie zaniechań powodowało widoczny nieład. Istotnym problemem było też pogarszanie się stanu pomieszczeń, szczególnie tych, w których przechowywano dokumentację. Ich zły stan (zimno, wilgoć) powodował widoczną fizyczną degradację akt, której szlachta starała się przeciwdziałać, jeśli tylko mogła go naocznie stwierdzić lub została o nim poinformowana przez personel kancelaryjny. W roku 1723 sejmik średzki nakazał pisarzom ziemskim i grodzkim z terenu województw wielkopolskich usunięcie zaległości kancelaryjnych, czyli wpisanie zaległych wpisów (aktykacji) do protokołów rezygnacji, inskrypcji i relacji oraz ich oprawienia do czasu przyszłego sejmu pod karą odsunięcia od urzędu ${ }^{114}$.

Najwięcej uwagi poświęcano czynnościom sprawdzającym stan akt, czemu trudno się dziwić, ponieważ dzięki nim można było określić zakres podejmowanych środków zaradczych. W roku 1611 sejmik zakroczymski uchwalił podatek na rewizję

\footnotetext{
110 Ibidem.

111 Ibidem, s. 202.

112 Ibidem.

113 A.B. Zakrzew ski, Budowa archiwów..., s. 117.

114 Akt.sej.poz. 1696-1732, s. 958 (laudum z 22 II 1723).
} 
ksiąg sądowych, uzasadniając to zaniedbaniami kancelaryjnymi po śmierci pisarza zakroczymskiego. Spowodowała ona zaległości w przepisywaniu akt brudnopisowych, w wyniku czego czystopisów nie można było oprawiać ${ }^{115}$. Po wojnie ze Szwedami sejmik radziejowski obradujący w roku 1659, stwierdziwszy zły stan akt ziemskich, zakazał ich udostępniania, zanim nie zostanie dokonana rewizja przez rewizorów wyznaczonych z dwóch województw brzeskiego i inowrocławskiego ${ }^{116}$.

W 1628 roku szlachta lubelska, dowiedziawszy się od pisarza ziemskiego Mikołaja Stoińskiego odpowiedzialnego za stan akt trybunalskich oraz ziemskich lubelskich, przechowywanych w lubelskim klasztorze dominikanów, o złym stanie niektórych z nich, domagała się powołania przez sejmik komisarzy do ich rewizji. Była świadoma, że po sprawdzeniu może być konieczne podjęcie decyzji o przepisaniu jednostek aktowych znajdujących się w najgorszym stanie fizycznym (,zbutwiałych") i zamierzała pokryć koszty tej czynności ${ }^{117}$. Na podstawie uchwały szlachty sieradzkiej w 1693 roku rozpoczęto sprawdzanie akt grodzkich, ale komisarze wyznaczeni do przeprowadzenia tej czynności nie wykonali jej. Wobec tego sejmik wyznaczył inne osoby, które prawdopodobnie dokonały rewizji, lecz nie złożyły szlachcie żadnej relacji, o co sejmik się upomnia ${ }^{118}$. Kolejną rewizję sejmik sieradzki nakazał w roku 1703, polecając zwrócenie szczególnej uwagi na protokoły prowadzone przez regenta sieradzkiego Marcina Dzikowskiego ${ }^{119}$.

Determinację $\mathrm{w}$ doprowadzeniu do rewizji akt ziemskich wykazała szlachta chełmska. Na sejmiku w roku 1636 zaleciła swoim posłom, aby domagali się reasumpcji konstytucji z roku $1631 \mathrm{w}$ sprawie rewizji akt chełmskich i krasnostawskich $^{120}$. Potem powtarzano ten postulat na późniejszych sejmikach. W 1639 roku rozszerzono ten postulat o akta podkomorskie i przeznaczono na przeprowadzenie tej czynności oraz przepisanie akt jeden pobór ${ }^{121}$. Na kolejnych sejmikach, w latach $1643^{122}$ i $1645^{123}$, ponawiano postulat rewizji, a w tym ostatnim roku domagano się reasumowania konstytucji z roku $1638 \mathrm{w}$ sprawie przepisania akt ziemskich chełmskich. Podobne postulaty pojawiały się też w następnych latach z powołaniem się na kolejne konstytucje sejmowe, ale rezolucje nie przynosiły większych rezultatów. W roku 1662 nawet powołano rewizorów w osobach pisarzy ziemskich i grodzkich oraz urzędników ziemskich ${ }^{124}$. Pięć lat później uchwalono rewizję nie tylko akt ziemskich i podkomorskich, ale również grodzkich ${ }^{125}$, ale wykonanie tego

115 A. Moniuszko, Wybrane aspekty ekonomiczne funkcjonowania sądownictwa grodzkiego i ziemskiego na Mazowszu w pierwszej połowie XVII wieku [w:] Nad społeczeństwem staropolskim, t. II: Polityka i ekonomia-społeczeństwo i wojsko-religia i kultura w XVI-XVIII wieku, red. D. We re da, Siedlce 2009, s. 46.

116 Lauda i instrukcje 1572-1764, s. 96.

117 Akta sejmikowe województwa lubelskiego..., s. 349.

118 A. Burkietowicz, op. cit., s. 60.

119 Ibidem.

${ }^{120}$ Akta sejmikowe ziemi chetmskiej..., s. 193 (z 9 XII 1636).

121 Ibidem, s. 212 (instrukcja z 25 I).

122 Ibidem, s. 244 (instrukcja z 2 I).

123 Ibidem, s. 256 (laudum z 2 I).

124 Ibidem, s. 512 (laudum z 12 VI).

125 Ibidem, s. 624 (laudum z 2 VI). 
postanowienia było znacznie trudniejsze niż wcześniej, ponieważ akta sądów szlacheckich były w Zamościu i przed dokonaniem sprawdzenia należało je przywieźć do miasta. $Z$ tego powodu późniejsze postanowienia z roku 1668 również nie zostały wykonane ${ }^{126}$.

Wśród postulatów ważnym problemem było też opracowanie akt. Czynności porządkowe w niektórych przypadkach musiano rozpocząć od wykonania zaniedbanej czynności kancelaryjnej, polegającej na zbieraniu zalegających i porozrzucanych w różnych miejscach składek brudnopisowych i czystopisowych oraz ich łączeniu zgodnie $\mathrm{z}$ zasadą porządku rzeczowo-chronologicznego. Tak było $\mathrm{w}$ roku 1673 w kancelarii ziemskiej inowrocławskiej, w której po śmierci pisarza Głembockiego pozostawały w nieładzie. $Z$ tego powodu sejmik kujawski obradujący w Radziejowie polecił urzędnikom ziemskim, aby uporządkowali akta luźne i protokoły (,,akta, seksterna, i protokóły pokorygowali”), a następnie sporządzili ich ewidencję (,regestra”). Interesujące, że zakazano im w trakcie wykonywania tej pracy udostępniania akt pisarzowi ziemskiemu Marcinowi Mikołajewskiemu ${ }^{127}$.

W 1765 roku ten sam sejmik radziejowski polecił wykonanie czynności porządkowych w odniesieniu do akt zapisów (transakcji) sędziemu ziemskiemu brzeskiemu Przyłubskiemu, zobowiązując się do wyasygnowania na ten cel odpowiednich funduszy ${ }^{128}$. Jednocześnie polecił regentom kancelarii grodzkich kujawskich, aby zajęli się organizacją przepisywania na czysto znajdujących się w nich akt brudnopisowych tzw. protokołów (,ich aktykancją"), aby można było je później oprawić. Do tych prac zalecono zatrudnienie młodzieży szlacheckiej, aby mogła nabyć doświadczenie w pracy kancelaryjnej oraz uzyskać pewien dochód z funduszy, które sejmik miał przydzielić pisarzom grodzkim ${ }^{129}$.

Rok później, w roku 1766, sejmik radziejowski uczynił dalszy krok w sprawie porządkowania, uchwalając wysoką kwotę 6700 zł na aktykowanie, czyli przepisanie z protokołów na czysto ksiąg podkomorskich, ziemskich i grodzkich obu województw kujawskich ${ }^{130}$. Miała być wypłacona $\mathrm{z}$ sum uzyskanych w ramach poboru czopowego. Za wydatkowanie tej kwoty i organizację prac porządkowych uczyniono odpowiedzialnymi pisarzy oraz regentów kancelarii, a kontrolę wykonanych prac powierzono rewizorom wybranym przez sejmik. Szlachcie bardzo zależało na doprowadzeniu porządkowania do końca, ponieważ zastrzegła wyasygnowanie dodatkowych kwot na wykonanie tej czynności ${ }^{131}$.

Jednocześnie wydano bardziej szczegółowe zalecenia dotyczące zakresu prowadzonych prac oraz sposobu ich wykonania. Księgi uszkodzone i mało czytelne z powodu złego przechowywania (,starością podarte i pobutwiałe”) miały być przepisa$\mathrm{ne}^{132}$. Do tej pracy zalecono angażowanie sprawdzonych kancelarystów (probatae fidei), piszących wyraźnie i koniecznie młodych, którzy dzięki temu mogli zdobyć

\footnotetext{
${ }^{126}$ Ibidem, s. 669 (laudum z 23 VII), 682 (laudum z 13 VIII).

${ }^{127}$ Lauda i instrukcje 1572-1764, s. 417-418.

${ }^{128}$ Lauda i instrukcje 1733-1795, s. 211.

129 Ibidem.

${ }^{130}$ Ibidem, s. 234.

131 Ibidem.

132 Ibidem, s. 235.
} 
doświadczenie kancelaryjne ${ }^{133}$. Zastrzeżono, że czystopisy powinny być sporządzone odpowiednio, czyli z zachowaniem marginesów lewego i prawego na półtora cala, dla miejsca na oprawę. Wprowadzono też wymaganie, aby na każdej stronie nie było więcej niż 20 wierszy zapisanych pismem ,równym i nierozciągłym” na papierze grubszym, tzw. dychtowym, aby tekst nie był widoczny na odwrocie. Ustalono też stawkę za przepisywanie w wysokości 15 gr od arkusza ${ }^{134}$.

Wśród prac o charakterze archiwalnym bardzo ważne miejsce zajmowało ewidencjonowanie. W artykule Chorążyczewskiego i Syty wskazano na laudum sejmiku radziejowskiego z 1754 roku. Ten sam sejmik uchwalił wynagrodzenie dla regenta i wiceregenta ziemskich inowrocławskich za poprawę stanu fizycznego akt grodzkich i ziemskich („reperację”) oraz regestowanie ksiąg grodzkich inowrocławskich i kruszwickich ${ }^{135}$. Sugeruje to prowadzenie prac porządkowych na wyższym poziomie, polegających na szczegółowym opisie zawartości poszczególnych woluminów. $\mathrm{Z}$ treści cytowanego źródła wynika, że chodziło o regestrowanie ${ }^{136}$, czyli rejestrowanie akt, polegające na tworzeniu prostego spisu istniejących jednostek archiwalnych, który niekiedy nazywano też inwentarzem. Jego przygotowanie wymagało jednak wykonania kilku innych czynności, przede wszystkim wcześniejszego uporządkowania akt i nadania im układu, najczęściej chronologicznego. Czynności z tym związane można było wykonać zespołowo przy pomocy zatrudnionego w kancelarii personelu kancelaryjnego i pomocniczego.

Przeprowadzenie prac inwentaryzacyjnych stawało się nie tylko postulatem wysuwanym w czasie obrad innych sejmików. Dobry przykład stanowiły sejmiki kijowski i bracławski oraz stosowana przez nie praktyka. W 1684 roku po spaleniu części ksiąg grodzkich owruckich, które były przechowywane w jednym z tamtejszych klasztorów, szlachta kijowska domagała się ,zinwentowania” ocalałych tomów przez wyznaczonych rewizorów, oblatowania sporządzonego inwentarza w aktach grodzkich i przekazania go staroście owruckiemu lub jego urzędnikom ${ }^{137}$. Księgi grodzkie żytomierskie przez pewien czas zdeponowane u biskupa łuckiego zostały wtedy ,zinwentowane"138. Potem odebrał je podstarości grodzki włodzimierski i sędzia ziemski kijowski Jan Wojnarski, a po jego śmierci przekazano je urzędnikom grodzkim żytomierskim. W roku 1717 sejmik bracławski zobowiązał regenta grodzkiego winnickiego do „regestrowania” ksiąg grodzkich winnickich i okazania ich wybranym przez szlachtę komisarzom ${ }^{139}$.

Niewiele natomiast wiadomo o zalecaniu przez sejmiki opracowywania w kancelariach sądów szlacheckich quasi-sumariuszy zawierających zazwyczaj zróżnicowane co do formy i treści informacje o wpisach stanowiących zawartość ksiąg, obejmujące nazwiska występujących przed urzędem lub sądem stron, a czasem tylko jednej, oraz krótką wzmiankę o rodzaju wpisu lub transakcji. Nie można ich

\footnotetext{
133 Ibidem.

134 Ibidem.

135 W. Chorąży c zew s k i, K. S y t a, Stosunek szlachty polskiej..., s. 20-21.

136 Lauda i instrukcje 1733-1795, s. 131.

137 AJZR, č. II, t. 2, Kiev' 1888, s. 462 (laudum z 13 IX).

138 Ibidem, t. 3, Kiev' 1910, s. 143 (laudum z 16 IX).

139 Ibidem, s. 521 (laudum z 16 III).
} 
nazywać sumariuszami, gdyż tym mianem z reguły określa się pomoce archiwalne znacznie bardziej precyzyjne, zawierające szczegółowe dane o wszystkich wpisach zawartych w jednostce aktowej (księdze, nieoprawionym woluminie) i stanowiące efekt konsekwentnie prowadzonej pracy analitycznej. Obejmują one precyzyjne informacje o czynnościach prawnych, w których wyniku powstały wpisy, oraz o osobach biorących w nich udział ${ }^{140}$.

W aktach sejmikowych odnalazłem tylko jeden ślad prowadzenia prac quasi-sumaryzacyjnych, z czego oczywiście nie wynika, że nie pociągały za sobą zainteresowania szlachty z innych terenów Rzeczypospolitej. Ten istotny problem wymaga jednak dalszych badań. Ten jedyny znany mi dowód czynności quasi-sumaryzacyjnych zawiera laudum szlachty brzesko-litewskiej z roku 1778. Uchwalono w nich wynagrodzenie prac, które prowadził regent ziemski brzeski Ignacy Hruszewski, przeznaczając na to część podymnego (w wysokości 1 gr od każdego dymu z dóbr zarówno duchownych, jak i świeckich). Co prawda czynności prowadzone przez niego określono w tekście uchwał jako regestrowanie akt („regestraturę”) ${ }^{141}$, z treści fragmentu wynika jednak, że nie chodziło o sporządzenie spisu akt, ale bardziej szczegółową charakterystykę ich zawartości.

Wspomniano bowiem, że prace prowadzone przez Hruszewskiego miały objąć akta ziemskie od ich rozpoczęcia, czyli od roku 1568. Pierwszy tom tej „regestratury" został okazany szlachcie uczestniczącej w sejmiku, co zyskało akceptację zgromadzonych i zapewne bezpośrednio przyczyniło się do podjęcia korzystnej dla tego regenta decyzji w sprawie jego wynagrodzenia. Hruszewski zobowiązał się wobec wszystkich obecnych do opracowania trzech dalszych tomów quasi-sumariusza w ciągu trzech lat, a także obiecał oprawienie wszystkich akt ziemskich oraz „regestrów”"142. Charakterystyczne, że ta pomoc archiwalna miała objąć „akta wieczyste", czyli, jak można przypuszczać, tzw. inskrypcje obejmujące różnego rodzaju transakcje o charakterze majątkowym, istotne dla szlachty ze względów dowodowych.

\section{PROBLEM ODZYSKIWANIA UTRACONEJ LUB NIEPRZEKAZANEJ DOKUMENTACJI}

Działania mające na celu odzyskiwanie utraconych akt rozszerzały zakres zainteresowania sejmików zagadnieniami dokumentacyjnymi. Szlachta zwracała uwagę na akta, które w następstwie różnych okoliczności znalazły się nie tylko poza kancelariami, ale obszarami, które one obsługiwały. Bardzo zależało jej na odzyskaniu akt i zwróceniu ich urzędom, w których były one pierwotnie przechowywane. Dążenie

\footnotetext{
140 Przykładem są sumariusze Metryki Koronnej sporządzane przez T. Wierzbowskiego w serii „Matricularum Regni Poloniae Summaria” czy też ich kontynuacja przez współczesnych archiwistów.

${ }^{141}$ Akty izdavaemye Vilenskô̂ Archeografičeskô̂ Kommissiêu dlâ razbora drevnich' aktov' (dalej: AVAK), t. IV, Vil'na 1892, s. 603.

${ }^{142}$ Ibidem.
} 
do kompletowania zasobu stanowiło charakterystyczny przejaw świadomości znaczenia dokumentacji. W rozumieniu szlachty należało chronić nie tylko wybrane księgi czy akta, ale całość zgromadzonych materiałów.

Szlachta miała świadomość negatywnych skutków wszelkich ubytków w dokumentacji. Brak potrzebnych akt powodował niemożność uzyskiwania z nich odpisów różnych dowodów prawnych zawartych w aktach, a to w praktyce bardzo utrudniało stronom pozbawionym dokumentów prowadzenie procesów sądowych. Stanowiło także poważną przeszkodę w zawieraniu różnego rodzaju transakcji. Nic dziwnego, że szlachta przybywająca na sejmiki była zainteresowana uzupełnianiem wszelkich braków w dokumentacji, dając temu wyraz zarówno w laudach, jak i instrukcjach sejmikowych.

Problemem tym zajęli się cytowani wyżej Chorążyczewski i Syta ${ }^{143}$. Opisali kilka przypadków starań o odzyskanie ksiąg podkomorskich w roku 1653 z rąk spadkobierców podkomorzego sanockiego Jana Adama Stadnickiego oraz akt podkomorskich, które zostały przejęte przez krewnych podkomorzego krakowskiego Jana Karola Czartoryskiego zmarłego w $1680 \mathrm{roku}^{144}$. W tej drugiej sprawie podejmowano jeszcze starania w roku 1687, ponieważ wcześniejsze działania nie przyniosły żadnych rezultatów. Podobne kroki podejmował sejmik gospodarski w Haliczu w latach 1728-1730 w celu odzyskania materiałów aktowych po trzech podkomorzych ${ }^{145}$.

W wymienionym artykule scharakteryzowano też postulaty szlachty zebranej na sejmiku ziemi dobrzyńskiej zawarte w instrukcji poselskiej z roku $1718 \mathrm{w}$ sprawie zwrócenia przez Prusy akt dotyczących ziemi dobrzyńskiej oraz dokumentów lokacyjnych kościołów z tego terenu, które znajdowały się w Królewcu. Podobne postulaty pojawily się w instrukcjach z roku $1735 \mathrm{i} 1765^{146}$. Szlachta ruska upominała się o księgi sądowe ze wschodnich ziem Rzeczypospolitej zajętych przez wojska rosyjskie w XVII wieku. Zainteresowani nimi posiadacze ziemscy musieli jeździć do Kijowa i Smoleńska oraz ponosić związane z tym koszty i niewygody. Postulaty $\mathrm{w}$ tej sprawie zgłaszała szlachta województwa kijowskiego zebrana w roku 1682 we Włodzimierzu, oraz uczestnicy sejmiku województwa bracławskiego zebrani w Winnicy w roku $1720^{147}$. Charakterystyczne, że podobne postulaty szlachta tych ziem zgłaszała jeszcze w roku 1744, a nawet i później ${ }^{148}$.

W kwestii postulatów szlacheckich mających na celu odzyskanie akt urzędowych od osób prywatnych można podać znacznie więcej faktów. W 1639 roku sejmik wiszeński w instrukcji dla swoich posłów poparł skargę pisarza grodzkiego żydaczowskiego Aleksandra Bronowskiego na sukcesorów swojego poprzednika, którzy zaniedbali swoje obowiązki, doprowadzając do bałaganu w dokumentacji, w wyniku czego nowy pisarz musiał przejąc ją bez jakiegokolwiek rejestru, a także spowodowali utratę części tzw. productów, czyli akt złożonych przez strony w celu wpisania

\footnotetext{
143 W. Chorąży czew ski, K. Syta, Stosunek szlachty polskiej..., s. 21-24.

144 Ibidem, s. 21-22.

145 Ibidem.

146 Ibidem, s. 22.

147 AJZR, č. II, t. 2, Kiev' 1888, s. 429 (z 16 XII 1720); č. II, t. 3, Kiev’ 1910, s. 655 (z 22VIII).

148 W. Chorąży c zew s ki, K. Sy ta, Stosunek szlachty polskiej..., s. 23.
} 
do ksiąg urzędowych ${ }^{149}$. Sejmik zobowiązał swoich posłów, by pozwali do sądu ziemskiego sukcesorów pisarza i żądali od nich zwrotu brakujących akt ${ }^{150}$.

Przed podobnym problemem stanęła szlachta krakowska zgromadzona na sejmiku w Proszowicach, rozpatrując skargę części zgromadzonej szlachty z powodu niezwrócenia akt podkomorskich po śmierci podkomorzego krakowskiego księcia Jana Karola Czartoryskiego ${ }^{151}$. Sejmik jednoznacznie poparł szlacheckie starania o odzyskanie akt, zobowiązując przyszłych posłów, by nakłonili wdowę do zwrotu brakujących akt po zmarłym podkomorzym, Magdalenę z Konopackich Czartoryską lub brata zmarlego, ks. Michała Jerzego Czartoryskiego, wojewody sandomierskiego ${ }^{152}$.

W innej instrukcji dla posłów, z roku 1669, sejmik wiszeński upomniał się o protokół inskrypcji grodzkich lwowskich, czyli księgi stanowiącej podstawę dla późniejszych wpisów czystopisowych, w której odnotowywano treść transakcji zawieranych przez szlachtę ${ }^{153}$. Księgę tę $\mathrm{w}$ okresie pełnienia funkcji przez podstarościego grodzkiego Wiszowatego, nieżyjącego już w momencie sporządzania instrukcji, przekazano do bliżej nieokreślonego „sądu” w Warszawie ${ }^{154}$. Posłów zobowiązano, aby odebrali księgę, przywieźli ją ze stolicy do Lwowa i przekazali do kancelarii grodzkiej ${ }^{155}$. W 1683 roku uczestnicy sejmiku wiszeńskiego zatroszczyli się o przekazanie nowo mianowanemu podkomorzemu przemyskiemu Janowi Wojakowskiemu akt podkomorskich, które były przechowywane w kancelarii ziemskiej w okresie wakansu na urzędzie podkomorzego ${ }^{156}$. Nakazali bowiem miejscowemu komornikowi granicznemu odebranie akt od spadkobierców pisarza ziemskiego przemyskiego Stanisława Fredry w obecności przemyskich urzędników sądowych, sędziego, podsędka oraz pisarza grodzkiego, podczas obrad sądów fiskalnych tej ziemi i przekazanie podkomorzemu ${ }^{157}$.

Także sejmik wielkopolski w Środzie okazywał zainteresowanie kwestią odzyskania brakujących akt. W swoim laudum z roku 1696 zobowiązał swojego marszałka, starostę odolanowskiego Stanisława Leszczyńskiego, by listownie zwrócił się z prośbą do Tomasza Działyńskiego, krajczego koronnego i ekonoma malborskiego oraz Kazimierza Ludwika Bielińskiego, podkomorzego koronnego i starosty malborskiego, aby zgodzili się na zwrot z zamku malborskiego ksiąg ziemskich z terenu województw wielkopolskich. Akta te trafiły do Malborka podczas potopu szwedzkiego i do tego czasu nie wróciły na swoje pierwotne miejsce przechowywania ${ }^{158}$.

149 Agz, t. XX, s. 428, pkt 52 (instrukcja z 25 VIII 1639). Nie wspomniał o tej sprawie P. Dąbkowski. Por. idem, Z przeszłości ksiag grodzkich i ziemskich żydaczowskich [w:] Księga pamiątkowa ku czci Bolesława Orzechowicza, t. 1, Lwów 1916.

${ }^{150}$ Agz, t. XX, s. 428, pkt 52.

151 Akt.sej.kr, t. V, s. 53 (uchwały sejmiku relacyjnego 18-22 V 1683).

152 Ibidem. Zob. też W. Chor ąży c ze w s k i, K. S y ta, Stosunek szlachty polskiej..., s. 22.

153 Agz, t. XXI, s. 524, pkt 71 (instrukcja z 20 VIII 1669).

154 Ibidem.

155 Ibidem.

156 Ibidem, t. XXII (Lauda wiszeńskie 1673-1732), oprac. A. Prochaska, Lwów 1914, s. 161, pkt 11 (laudum z 24 V 1683).

157 Ibidem.

158 Ibidem, t. XXI, s. 524, pkt 71 (instrukcja z 20 VIII 1669). 
Najciekawsze, że w tej sprawie sejmik już zwracał się do króla Jana III Sobieskiego, uzyskując od niego korzystny reskrypt ${ }^{159}$, którego wydanie wcale nie spowodowało zwrotu dokumentacji. Ten sam sejmik z inicjatywy Wojciecha Gruszczyńskiego, regenta grodzkiego gnieźnieńskiego, w 1705 roku zaangażował się również w sprawę przekazania akt grodzkich gnieźnieńskich z zamku poznańskiego do Gniezna ${ }^{160}$. Zobowiązano wtedy regenta grodzkiego Jana Ryszarda Grabowskiego do spisania ksiąg i przekazania ich regentowi gnieźnieńskiemu ${ }^{161}$.

Również inne sejmiki interesowały się losem akt pozostających w rękach prywatnych. W roku 1575 szlachta chełmska poleciła miejscowym urzędnikom ziemskim sędziemu i pisarzowi, aby razem z nowo obranym podsędkiem ziemskim Ambrożym Żulińskim okazali akta ziemskie na następnym sejmiku ${ }^{162}$. Można to interpretować jako dążenie do skontrolowania ich kompletności po śmierci poprzedniego podsędka. W 1670 roku uczestnicy sejmiku sieradzkiego uchwalili przekazanie komornikowi brzeskiemu ksiąg podkomorskich podkomorzemu sieradzkiemu Aleksandrowi Kazimierzowi Zapolskiemu, ale uchwała w tej sprawie, tak jak i następna nie zostały zrealizowane ${ }^{163}$.

Osobną grupę akt, którymi zainteresowała się szlachta, stanowiły materiały pozostałe po działalności sądów kapturowych. Dobry przykład stanowią uchwały zjazdów ziemian przemyskich z lat trzydziestych XVIII wieku. W roku 1737 regent sądów kapturowych i jednocześnie susceptant grodzki Opacki nie przekazał akt sądu kapturowego miejscowej kancelarii ziemskiej. Polecono więc palestrantom przemyskim Janowi Uruskiemu i Janowi Jaworskiemu, by przejęli z rąk regenta, uporządkowali je według serii, oddzielając protokoły od indukty i przekazali do kancelarii ziemskiej ${ }^{164}$. Sejmik wiszeński obradujący miesiąc później potwierdził przejęcie przez wymienionych palestrantów akt sądów kapturowych od Opackiego. Jednocześnie zwrócono uwagę na zaległości w indukowaniu akt, które miały być przez nich niezwłocznie usunięte ${ }^{165}$.

W roku 1739 prace związane z przejęciem akt $\mathrm{i}$ ich uporządkowaniem zostały zakończone, więc powołano rewizorów do skontrolowania akt i ich ewidencji w osobach Jana Jaworskiego i Andrzeja Nowosielskiego, którym przyznano za te prace po $200 \mathrm{zz}^{166}$. W roku następnym ten drugi na zjeździe ziemian przemyskich okazał zgromadzonym oprawne tomy akt sądów kapturowych, licząc na finansową rekompensatę nakładów poniesionych $\mathrm{w}$ związku z porządkowaniem i oprawą akt. Szlachta, nie mogąc uregulować wszystkich należności, poleciła wypłacić mu tylko drobną kwotę 50 zł, obiecując zapłacić należność w przyszłości ${ }^{167}$. W 1740 roku sejmik wiszeński upomniał się o dokumentację pozostałą po Janie Karolu Mniszchu,

\footnotetext{
159 Ibidem.

${ }^{160}$ Akt.sej.poz. (1696-1732), s. 467 (laudum z 30 III 1705).

161 Ibidem.

162 Akta sejmikowe chetmskie..., s. 44-45 (laudum z 31 III 1705).

163 A. Burkietowicz, op. cit., s. 58.

164 Agz, t. XXIII, s. 166, poz. 18 (uchwały z 19 VIII 1737).

165 Ibidem, s. 169, poz. 15 (uchwały z 10 IX 1737).

166 Ibidem, s. 179, poz. 8.

167 Ibidem, s. 189, pkt 4 (uchwały z 4 IV 1740).
} 
marszałku konfederacji województwa ruskiego, które miały zostać przekazane kasztelanowi przemyskiemu Mikołajowi Aleksandrowi Sołtykowi, a potem powinny trafić ostatecznie do archiwum ziemskiego ${ }^{168}$.

\section{WNIOSKI}

1. Dzięki przedwojennym pracom Dąbkowskiego i Kostkiewicza znane były przejawy zainteresowania stanem zabezpieczenia akt ziemskich, grodzkich i podkomorskich sejmiku generalnego ruskiego gromadzącego się w Sądowej Wiszni oraz sejmików ziemskich lwowskiego, przemyskiego, sanockiego oraz halickiego, odbywanych w stolicach tych ziem. Nie dokonano wtedy odrębnej analizy tego problemu. W powojennych opracowaniach Chorążyczewskiego i Syty oraz Zwierzykowskiego przedstawiono szereg faktów obrazujących troskę o dokumentację, jaką przejawiały sejmiki: kujawski, dobrzyński i wielkopolski. Do tej pory jednak brakowało publikacji poświęconej wyłącznie aktywności sejmików w sprawach dokumentacyjnych.

2. Dokonana analiza stanowiska trzech opiniotwórczych sejmików: krakowskiego, wielkopolskiego oraz ruskiego, uzupełniona informacjami pochodzącymi z laudów sejmikowych chełmskich, a incydentalnie innych sejmików, potwierdziła stałą troskę uczestniczącej w nich szlachty o los akt zgromadzonych w kancelariach sądów szlacheckich. Pozwoliła też na dokonanie nowych ustaleń dotyczących szczególnego stosunku szlachty do dokumentacji sądowej, pomieszczeń archiwalnych, w których była przechowywana, a także sposobu sporządzania akt oraz ich ewidencjonowania.

3. Udało się też stwierdzić, że szlachta z różnych terenów bardzo ceniła akta ziemskie i grodzkie, co znajdowało wyraz w określaniu ich jako archiwów „fortun naszych". Zdawała sobie bowiem sprawę, że znajdują się w nich dowody jej stanu posiadania w postaci kontraktów kupna-sprzedaży, darowizny czy też cesji. Często używane w laudach sformułowania o konieczności podejmowania przez szlachtę starań o poprawę stanu przechowywania akt nie miały więc jedynie charakteru czysto retorycznego. Są dowody świadczące, że w niektórych przypadkach dokumentacja sądów grodzkich i ziemskich mogła być traktowana jako świadectwo przynależności do stanu szlacheckiego oraz aktywności politycznej.

4. Liczne uchwały dowodzą, że szlacheccy uczestnicy sejmików nie tylko wyrażali opinie w sprawach bezpieczeństwa akt, ale przeznaczali spore kwoty na remont pomieszczeń kancelaryjnych pełniących funkcję magazynów aktowych (,sklepów”), rewizję akt, ich porządkowanie, oprawę i sporządzanie rejestrów. Zdarzało się też, że szlachta decydowała się na dokonanie zakupu kamienic na potrzeby kancelarii ziemskich (np. w Przemyślu i Lwowie). To rozwiązanie świadczyło o zapobiegliwości tej szlachty, która w ten sposób chciała stworzyć lepsze warunki do pracy

168 Ibidem, s. 201, pkt 13 (laudum z 13 IX 1740). 
personelowi kancelaryjnemu i skuteczniej chroniła zgromadzone tam akta. Należy dodać, że w innych powiatach i ziemiach kancelarie nie miały stałych siedzib.

5. Z przykładu lwowskiego wynika ważny wniosek, że właściwe utrzymanie kamienicy było bardzo kosztowne, a uzyskiwane dochody nie pokrywały kosztów jej remontów, co skłoniło miejscowy sejmik gospodarski do sprzedaży budynku i wynajmowania u innych właścicieli pomieszczeń dla kancelarii ziemskiej i archiwum. Ze względów ekonomicznych korzystniejsze okazywało się więc drugie rozwiązanie, gdyż koszty utrzymywania budynków, w których przechowywano akta, musieli pokrywać właściciele.

6. Wśród szlacheckich postulatów związanych z dokumentacją ważne miejsce zajmowała kwestia porządkowania akt grodzkich i ziemskich. Zwracano uwagę na potrzebę formowania jednostek archiwalnych, ich systematyzacji w porządku rzeczowo-chronologicznym, oprawy oraz ewidencjonowania w formie spisów. Zdarzały się też przypadki szczegółowego regulowania sposobu sporządzania indukty z precyzyjnym określeniem wielkości marginesów, jakości pisma, a nawet gatunku papieru (laudum radziejowskie z 1766 roku).

7. Poza jednym przypadkiem (laudum brzesko-litewskie z 1778 roku) nie udało się natomiast stwierdzić zalecania bądź wyrażania akceptacji i finansowania przez sejmiki prac quasi-sumaryzacyjnych, polegających na dokładniejszym opisywaniu zawartości ksiąg. Można przypuszczać, że tego rodzaju czynności związane z opracowaniem akt, pracochłonne i wymagające od kancelarystów wysokich kwalifikacji zalecano rzadko, ponieważ pociągały za sobą znaczne koszty.

8. Ziemianie zgromadzeni na sejmikach zwracali uwagę na potrzebę odzyskiwania brakujących akt, które po wypożyczeniu nie zostały zwrócone. Troszczyli się też o przekazanie dokumentacji pozostającej w rękach krewnych zmarlych urzędników kancelaryjnych. Niejednokrotnie domagali się także zwrotu dokumentacji, która znajdowała się w posiadaniu pruskim lub rosyjskim, ale dalej była przydatna dla polskiej szlachty. Tego rodzaju starania stanowiły przejaw świadomości znaczenia pełnej dokumentacji określonych sądów, a nie tylko wybranych woluminów.

9. Odzwierciedlona w laudach i instrukcjach sejmikowych troska ziemian wymienionych województw i ziem o pomieszczenia kancelaryjne, archiwalne, odpowiednie warunki przechowywania zgromadzonej w nich dokumentacji oraz o należyty ich porządek wynikała ze świadomości znaczenia dokumentacji i potrzeby jej szczególnej ochrony. Była ona następstwem świadomości prawnej, a także powszechnego dążenia do zachowania posiadanych majątków.

10. Przedstawione ustalenia mają charakter wstępny ze względu na wykorzystanie jedynie części materiału źródłowego. $Z$ tego powodu badania problemu zainteresowania sejmików dokumentacją sądów ziemskich, grodzkich i podkomorskich powinny być prowadzone dalej, ze szczególnym uwzględnieniem uchwał sejmikowych i instrukcji sejmików litewskich poznanych słabiej niż akta sejmikowe ziem koronnych. 


\section{BIBLIOGRAFIA}

\section{Źródła rękopiśmienne}

Archiwum Państwowe w Lublinie, Księgi grodzkie chełmskie. Relationes, manifestationes, oblatae, syg. $61,70,72,74,93,106,111$.

Archiwum Państwowe w Lublinie, Księgi grodzkie krasnostawskie. Relationes, manifestationes, oblatae, syg. 5.

\section{Źródła drukowane}

Akta grodzkie i ziemskie z czasów Rzeczypospolitej Polskiej z archiwum tak zwanego bernardyńskiego we Lwowie, t. XX (Lauda sejmikowe wiszeńskie 1572-1648), wyd. A. Prochaska, Lwów 1909; t. XXI (Lauda sejmiku wiszeńskiego 1648-1673), wyd. A. Prochaska, Lwów 1911; t. XXII (Lauda sejmiku wiszeńskiego 1673-1732), wyd. A. Proch a ska, Lwów 1914; t. XXIII (Lauda sejmikowe wiszeńskie, lwowskie, przemyskie i sanockie 1731-1772), wyd. A. Pr o ch a sk a, Lwów 1928; t. XXV (Lauda sejmikowe halickie 1696-772), wyd. W. Hej nos z, Lwów 1935.

Akta sejmikowe ziemi chetmskiej 1572-1668, oprac. W. B ond y ra, H. G miterek, J. Tern e s, Lublin 2013.

Akta sejmikowe województwa krakowskiego, t. I (1572-1620), wyd. S. Kutrzeba, Kraków 1932; t. II (1621-1660), wyd. A. Przybo ó, Kraków 1953; t. III (1661-1673), wyd. A. Przyboś, Kraków 1959; t. IV (1674-1680), wyd. A. Przyboś, Kraków 1963; t. V (1681-1696), wyd. A. Przy b oś, Kraków 1984.

Akta sejmikowe województw poznańskiego i kaliskiego lata 1696-1732, wyd. M. Zw i e r zy k ow s ki, Poznań 2008.

Akta sejmikowe województw poznańskiego i kaliskiego lata 1733-1763, wyd. M. Zwier zy k ow s ki, Poznań 2015.

Akty izdavaemye Vilenskoû Archeografičeskojû Kommissiê̂ dlâ razbora drevnich' aktov', t. IV, Vil'na 1892.

Archiv' Ûgozapadnoj Rossì izdavaemyj Vremiennoû kommìsìể dlâ razbora drevnich 'aktov', č. II, t. 2, Kiev' 1888; č. II, t. 3, Kiev' 1910.

Pawiński A., Dzieje ziemi kujawskiej oraz akta historyczne do nich stużace. Rzady sejmikowe $w$ epoce królów elekcyjnych 1572-1795, t. 2: Lauda i instrukcje 1572-1764; t. 4: Lauda i instrukcje 1700-1733; t. 5: Lauda i instrukcje 1733-1795, Warszawa 1888.

Volumina legum, t. IV, wyd. J. O hry zk o, Petersburg 1859.

\section{Opracowania}

B i ele ck a J., Kancelaria grodzka wielkopolska w XVI-XVIII wieku, „Studia Źródłoznawcze" 1957 , t. 1, s. 119-153.

B og d a n D., Sejmik warmiński w XVI i pierwszej połowie XVII wieku, Olsztyn 1994.

B urki et ow i c z A., Sejmik sieradzki w latach 1669-1717, Sieradz 2009.

Choińska-Mika J., Sejmiki mazowieckie w dobie Wazów, Warszawa 1998. 
Chorążyczewski W., Syta K., Stosunek szlachty polskiej $w X V-X V I I I$ w. do ksiag sqdów partykularnych $w$ świetle ustaw sejmowych $i$ sejmikowych, ,Miscellanea Historico-Archivistica" 1999, t. X, s. 3-26.

Chorążyczewski W., Syta K., Ustawodawstwo archiwalne sejmów polskich od XV do połowy XVIII w. Zarys problemu [w:] Archiwistyka i bibliotekoznawstwo. Prace dedykowane Profesorowi Bohdanowi Ryszewskiemu, Warszawa 1997, s. 30-53.

D ąb k ow sk i P., Księgi sądowe halickie za czasów polskich, „Przegląd Prawa i Administracji” 1917, s. 1-20.

Dąb kow sk i P., Księgi sądowe lwowskie w dawnej Polsce, „Studia nad historią prawa polskiego", t. XVI, z. 1, Lwów 1937, s. 1-158.

Dąbkowski P., Księgi sądowe przemyskie i przeworskie w dawnej Polsce, „Rocznik Towarzystwa Przyjaciół Nauk w Przemyślu" 1928-1937, t. VII, s. 3-86.

Dąbkowski P., Palestra i księgi sądowe sanockie $w$ dawnej Polsce, „Pamiętnik Historyczno-Prawny" 1925, t. 1, z. 6, s. 1-55.

Dąbkowski P., Palestra i księgi sądowe trembowelskie za czasów polskich, „Przegląd Prawa i Administracji” 1919, r. 44, z. 1, s. 1-57.

Dąb kow sk i P., Z przeszłości ksiagg grodzkich i ziemskich buskich, „Kwartalnik Historyczny" 1915 , t. 29 , s. $1-16$.

Dąbkowski P., Z przeszłości ksiag grodzkich i ziemskich żydaczowskich [w:] Księga pamiątkowa ku czci Bolesława Orzechowicza, t. 1, Lwów 1916, s. 234-255.

F ili p c zak-Ko c ur A., Sejmik sieradzki za Wazów (1587-1668), Opole 1989.

Gi e row s ki J.A., Sejmik generalny księstwa mazowieckiego, Wrocław 1948.

J o p R., Środowisko urzędnicze kancelarii grodzkich w Chetmie, Lublinie i Krasnymstawie $w$ drugiej połowie XVII wieku, Lublin 2003.

Kostkiewicz T., Działalność kulturalna sejmiku ruskiego, „Pamiętnik Historyczno-Prawny" 1939, t. 13, z. 2, s. 30-36.

Kozyrski R., rec.: R. Jop, Środowisko urzędnicze kancelarii grodzkich w Chełmie, Lublinie i Krasnymstawie w drugiej połowie XVII wieku, „Rocznik Chełmski” (2006) t. 10, s. 411-414.

Ko zy rski R., Sejmik szlachecki ziemi chetmskiej (1648-1717), Lublin 2006.

Ło sowski J., Kancelaria grodzka chetmska od XV do XVIII wieku. Studium o urzędzie, dokumentacji, jej formach i roli w życiu społeczeństwa staropolskiego, Lublin 2004.

Mazu r K., W strone integracji z Korona. Sejmiki Wotynia i Ukrainy w latach 1569-1648, Warszawa 2006.

Przyboś K., Sejmik województwa krakowskiego w czasach saskich (1697-1763), Kraków 1981.

R adaman A., Uchvalenne mâscovych podatkaŭ na sojmikach i šljacheckich z'ezdach Novagarodskaga vaâvodstva VKL u drugoj palove XVI - pačatky XVII st., „Belaruski Gistaryčny Časopis" 2013, nr 9, s. 22-33.

Robótka H., Rys zew ski B., Tom c zak A., Archiwistyka, Warszawa 1989.

Ternes J., Sejmik chetmski za Wazów (1587-1668), Lublin 2004.

To m c zak A., Zarys dziejów archiwów polskich, Torun 1982.

Traw i c k a Z., Sejmik województwa sandomierskiego w latach 1572-1696, Kielce 1985.

U j m a M., Sejmik lubelski 1572-1696, Warszawa 2003.

Urzędnicy województwa ruskiego XIV-XVIII wieku. Spisy, opr. K. Pr zy b o ś, Wrocław 1987.

Wło darc zy k J., Sejmiki łęczyckie, Łódź 1973.

Vilimas D., Lietuvos Didžiosios Kunigaikštystès žemès teismo sistemos formavimasis (1564-1588), Vilnius 2006. 
Zakrzewski A.B., Budowa archiwów szlachty trockiej, „Miscellanea Historico-Archivistica" 2000, t. XI, s. 111-118.

Zakrzewski A.B., Sejmiki Wielkiego Księstwa Litewskiego XVI-XVIII w. Ustrój i funkcjonowanie: sejmik trocki, Warszawa 2000.

Z w i e r zy k o w s k i M., Komisja Skarbowa Poznańska. Z dziejów sejmikowej administracji i sadownictwa skarbowego w Wielkopolsce w XVII i XVIII wieku, Poznań 2003.

Zwierzykowski M., Problematyka archiwalna w uchwałach sejmiku województw poznańskiego i kaliskiego w czasach saskich (1696-1763) [w:] Pamiętnik II Ogólnopolskiego Zjazdu Studentów Archiwistyki, Poznań 16-17 kwietnia 1998 r., red. I. Mamc zak-Gadkow ska, Poznań 1998.

Zwierzykowski M., Sejmikowe próby remontu zamku poznańskiego w XVIII wieku, „Kronika miasta Poznania” 2004, nr 4, s. 279-302.

Zwierzykowski M., Szlacheckie instytucje sadowe i samorzadowe na Starym Rynku od XVI do XVIII wieku, „Kronika miasta Poznania” 2003, nr 2, s. 238-248. 